\title{
EUCAARI ion spectrometer measurements at 12 European sites - analysis of new particle formation events
}

\author{
H. E. Manninen ${ }^{1}$, T. Nieminen ${ }^{1}$, E. Asmi ${ }^{2}$, S. Gagné ${ }^{1}$, S. Häkkinen ${ }^{1}$, K. Lehtipalo ${ }^{1}$, P. Aalto ${ }^{1}$, M. Vana ${ }^{1,3}$, A. Mirme ${ }^{3}$, \\ S. Mirme ${ }^{3}$, U. Hõrrak ${ }^{3}$, C. Plass-Dülmer ${ }^{4}$, G. Stange ${ }^{4}$, G. Kiss ${ }^{5}$, A. Hoffer ${ }^{5}$, N. Törő ${ }^{5}$, M. Moerman ${ }^{6}$, B. Henzing ${ }^{6}$, \\ G. de Leeuw ${ }^{1,2,6}$, M. Brinkenberg ${ }^{7}$, G. N. Kouvarakis ${ }^{8}$, A. Bougiatioti ${ }^{8}$, N. Mihalopoulos ${ }^{8}$, C. O'Dowd ${ }^{9}$, D. Ceburnis ${ }^{9}$, \\ A. Arneth $^{10}$, B. Svenningsson ${ }^{11}$, E. Swietlicki ${ }^{11}$, L. Tarozzi ${ }^{12}$, S. Decesari ${ }^{12}$, M. C. Facchini ${ }^{12}$, W. Birmili ${ }^{13}$, \\ A. Sonntag ${ }^{13}$, A. Wiedensohler ${ }^{13}$, J. Boulon ${ }^{14}$, K. Sellegri ${ }^{14}$, P. Laj $^{15}$, M. Gysel ${ }^{16}$, N. Bukowiecki ${ }^{16}$, E. Weingartner ${ }^{16}$, \\ G. Wehrle ${ }^{16}$, A. Laaksonen ${ }^{2,17}$, A. Hamed ${ }^{17}$, J. Joutsensaari ${ }^{17}$, T. Petäjä ${ }^{1}$, V.-M. Kerminen ${ }^{1,2}$, and M. Kulmala ${ }^{1,11,18}$ \\ ${ }^{1}$ Department of Physics, P.O. Box 64, 00014 University of Helsinki, Finland \\ ${ }^{2}$ Finnish Meteorological Institute, Research and Development, P.O. Box 503, 00101 Helsinki, Finland \\ ${ }^{3}$ Institute of Physics, University of Tartu, Ülikooli 18, 50090 Tartu, Estonia \\ ${ }^{4}$ Hohenpeissenberg Meteorological Observatory, German Meteorological Service, 82383 Hohenpeissenberg, Germany \\ ${ }^{5}$ Air Chemistry Group of Hungarian Academy of Sciences, University of Pannonia, P.O. Box 158, 8201 Veszprém, Hungary \\ ${ }^{6}$ Environment, Health and Savety, P.O. Box 80015, 3508 TA Utrecht, Netherlands Organisation for Applied Scientific \\ Research TNO, The Netherlands \\ ${ }^{7}$ Royal Netherlands Meteorological Institute KNMI, Regional Climate Division, P.O. Box 201, 3730 AE De Bilt, The \\ Netherlands \\ ${ }^{8}$ Environmental Chemical Processes Laboratory, Department of Chemistry, University of Crete, P.O. Box 2208, 71003, \\ Heraklion, Greece \\ ${ }^{9}$ School of Physics and Centre for Climate \& Air Pollution Studies, Environmental Change Institute, National University of \\ Ireland, Galway, Galway, Ireland \\ ${ }^{10}$ Lund University, Dept. Physical Geography and Ecosystem Analysis, Sölvegatan 12, 22362 Lund, Sweden \\ ${ }^{11}$ Department of Physics, Lund University, P.O. Box 118, 221 00, Sweden \\ ${ }^{12}$ Institute of Atmospheric Sciences and Climate, ISAC - CNR, Consiglio Nazionale delle Ricerche, Bologna, Italy \\ ${ }^{13}$ Leibniz Institute for Tropospheric Research, Permoserstrasse 15, 04303 Leipzig, Germany \\ ${ }^{14}$ Laboratoire de Météorologie Physique, Blaise Pascal Univ., 63000, Clermont-Ferrand, France \\ ${ }^{15}$ Laboratoire de Glaciologie et Géophysique de l'Environnement, Université de Grenoble 1 - CNRS, Grenoble, France \\ ${ }^{16}$ Paul Scherrer Institut, Laboratory of Atmospheric Chemistry, 5232 Villigen PSI, Switzerland \\ ${ }^{17}$ Department of Physics and Mathematics, University of Eastern Finland, Kuopio, 70211, Finland \\ ${ }^{18}$ Department of Applied Environmental Science (ITM), Stockholm University, Svante Arrheniusväg 8, 10691 Stockholm, \\ Sweden
}

Received: 6 April 2010 - Published in Atmos. Chem. Phys. Discuss.: 27 April 2010

Revised: 12 August 2010 - Accepted: 13 August 2010 - Published: 25 August 2010

\begin{abstract}
We present comprehensive results on continuous atmospheric cluster and particle measurements in the size range $\sim 1-42 \mathrm{~nm}$ within the European Integrated project on Aerosol Cloud Climate and Air Quality interactions (EUCAARI) project. We focused on characterizing the spatial and temporal variation of new particle formation events and
\end{abstract}

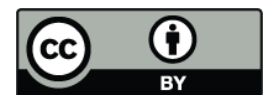

Correspondence to: H. E. Manninen (hanna.manninen@helsinki.fi) relevant particle formation parameters across Europe. Different types of air ion and cluster mobility spectrometers were deployed at 12 field sites across Europe from March 2008 to May 2009. The measurements were conducted in a wide variety of environments, including coastal and continental locations as well as sites at different altitudes (both in the boundary layer and the free troposphere). New particle formation events were detected at all of the 12 field sites during the year-long measurement period. From the data,

Published by Copernicus Publications on behalf of the European Geosciences Union. 
nucleation and growth rates of newly formed particles were determined for each environment. In a case of parallel ion and neutral cluster measurements, we could also estimate the relative contribution of ion-induced and neutral nucleation to the total particle formation. The formation rates of charged particles at $2 \mathrm{~nm}$ accounted for $1-30 \%$ of the corresponding total particle formation rates. As a significant new result, we found out that the total particle formation rate varied much more between the different sites than the formation rate of charged particles. This work presents, so far, the most comprehensive effort to experimentally characterize nucleation and growth of atmospheric molecular clusters and nanoparticles at ground-based observation sites on a continental scale.

\section{Introduction}

Trace gases and aerosol particles originating from natural and anthropogenic emissions are transported and transformed over geographically large areas, whereupon they influence on the radiative transfer, clouds and climate (e.g. Andrea and Rosenfeld, 2008). Gas-to-particle conversion via various nucleation mechanisms links trace gases to secondary aerosol formation (Kulmala, 2003), which has been observed to occur worldwide (Kulmala et al., 2004c; Kulmala and Kerminen, 2008; Venzac et al., 2008). The newly formed particles have been observed to grow into cloud condensation nuclei (CCN) sizes (e.g. Laaksonen et al., 2005; Wiedensohler et al., 2009) and ultimately to participate in cloud droplet activation (Kerminen et al., 2005). Modeling studies indicate that nucleation may be a significant source of new CCN in the global atmosphere (e.g. Spracklen et al., 2008; Merikanto et al., 2009; Pierce and Adams, 2009).

Despite the growing number of locations where frequent new particle formation has been observed, detailed formation and growth mechanisms of atmospheric aerosols are still unclear in many respects. For example, while ions are known to influence both nucleation and growth (e.g. Nadykto and Yu, 2003; Winkler et al., 2008), their overall effect on atmospheric aerosol formation has remained controversial (Enghoff and Svensmar, 2008; Kazil et al., 2008; Yu et al., 2008). The ambiguities in atmospheric nucleation mechanisms make it difficult to quantify the factors governing the frequency and strength of new particle formation in different environments. Many open questions remain with regard to the chemical composition and electric charge of nanometersize clusters. In addition, the microphysical structure of these clusters is not known, i.e. whether they are clusters or big molecules. In this paper we refer to all sub $2 \mathrm{~nm}$ particles as clusters. A deep understanding on all these issues is needed to assess the importance of secondary particle formation to the Earth's climate system.
Quantification of the new particle formation parameters, such as the particle formation and growth rates in different environments, is a crucial step towards understanding the role of small ions and particles in the global climate. The occurrence of the new particle formation events is controlled by a number of factors, including the origin of the air masses, production of low-volatile vapors, concentrations of aerosol precursor vapors, pre-existing aerosol population, meteorological parameters and radiation (e.g. Nilsson et al., 2001; Boy and Kulmala, 2002; Sogacheva et al., 2008; Bonn et al., 2009). Understanding the temporal variation of the new particle formation phenomenon and quantifying its influences on climate and air quality requires long-term, continuous field measurements. Therefore, a one-year-long European measurement campaign was conducted simultaneously at multiple stations using calibrated, inter-compared instruments.

As a part of the EUCAARI (European Integrated Project on Aerosol Cloud Climate Air Quality Interactions) project (Kulmala et al., 2009; Kerminen et al., 2010), different types of cluster mobility spectrometers were deployed simultaneously at different European sites representing a variety of geographical and atmospheric conditions to quantify the spatial and temporal distribution of particle formation events. The measurements presented here were initiated during March, 2008, and concluded between February and May, 2009. These intensive ion and particle measurements took place at 12 field sites across the Europe - Pallas and Hyytiälä (Finland), Vavihill (Sweden), Mace Head (Ireland), Cabauw (The Netherlands), Melpitz and Hohenpeissenberg (Germany), K-Puszta (Hungary), Jungfraujoch (Switzerland), Puy de Dôme (France), San Pietro Capofiume (Italy) and Finokalia (Greece) - and brought together many of the leading European research groups and the state-of-theart infrastructure. The different field sites represent a wide variety of environments, such as marine, coastal, remote continental, suburban, rural and mountain conditions. The field sites are located at different altitudes ranging from sea level to several thousands of meters above sea level (a.s.l.).

Prior to the EUCAARI project, ion spectrometers have been utilized continuously mainly in boreal forest region in Finland and Estonia (Hõrrak et al., 2003; Hirsikko et al., 2005, 2007; Manninen et al., 2009b). Shorter measurement time series have been obtained from France (Venzac et al., 2007), Himalayas (Venzac et al., 2008), Australia (Suni et al., 2008), South-Africa (Laakso et al., 2008), Ireland (e.g. Vana et al., 2008), Boulder in Colorado (Iida et al., 2006), Atlanta in Georgia (Eisele et al., 2006), Mexico City (Iida et al., 2008) and Antarctica (Virkkula et al., 2007). Furthermore, ion spectrometers have been used in a moving train between Moscow-Vladivostok in Russia (Vartiainen et al., 2007), in a hot-air balloon over Finland (Laakso et al., 2007a), on a ship over North Atlantic (Ehn et al., 2010), and onboard the aircraft over Europe (Mirme et al., 2010). In these studies, ion spectrometers were found to be important observational 
tools for atmospheric new particle formation. New particle formation event analysis - event classification, particle formation and growth rates calculations - for ion spectrometer data has already firm guidelines (Hirsikko et al., 2005, 2007; Kulmala et al., 2007; Manninen et al., 2009a).

Here, we present observations on atmospheric nucleation and first steps of growth at twelve EUCAARI sites. Air ion spectrometers were used to measure the mobility distributions of charged aerosol particles and clusters down to molecular sizes (Tammet, 2006; Mirme et al., 2007). Neutral cluster and air ion spectrometers measured additionally the mobility distribution of neutral particles larger than $2 \mathrm{~nm}$ in diameter by charging the aerosol sample with unipolar corona chargers (Kulmala et al., 2007; Manninen et al., 2009b). In general, ions were measured in the mobility diameter range of 0.8-42 nm, whereas neutral particles were measured in the range of $\sim 2-42 \mathrm{~nm}$. The atmospheric nucleation and cluster activation takes place at the mobility diameter range of 1.5$2 \mathrm{~nm}$ (Kulmala et al., 2007; Nieminen et al., 2009), or even at somewhat smaller sizes $(1.2-1.5 \mathrm{~nm})$ (Sipilä et al., 2010). Therefore, the ion spectrometers allow direct measurements at exactly the size where atmospheric nucleation takes place. The main purpose of this paper is to get new insight into atmospheric new particle formation over Europe. In addition to characterizing the spatial and temporal variability of nucleation events, we will investigate several quantities relevant to such events, including the particle formation and growth rates and, in case of parallel ion and neutral cluster measurements, also the contribution of ions to new particle formation.

\section{Materials and methods}

Cluster spectrometers, such as the Air Ion Spectrometer (AIS) and the Neutral cluster and Air Ion Spectrometer (NAIS), were operated at 12 field sites across Europe within the EUCAARI project. The cluster spectrometer measurements presented in this paper started in March 2008 before the EUCAARI Intensive Observation Period (IOP) in May 2009, and they ended between February and May 2008 depending on the site. Before and after the field measurements, the cluster spectrometers took part in a calibration and intercomparison workshop in Helsinki (Asmi et al., 2009; Gagné et al., 2010b). During the first calibration workshop, the focus was to calibrate the (N)AISs so that they could be reliably used in long-term cluster studies. Considering the short time period from their development, and the fact that these instruments are used to capture nanometer-sized ions and particles also in the size range below $3 \mathrm{~nm}$ not possible with other aerosol spectrometers, their performance for mobility and concentration measurements was found to be good (Asmi et al., 2009). The (N)AISs detected similar concentrations as the reference instruments at concentrations corresponding to particle formation events, but the mobilities were slightly overestimated.
The second calibration workshop focused on ensuring that the instruments had sustained their performance during the field measurements and to experimentally determine the (N)AIS transfer functions. Gagné et al. (2010b) aimed to compare the instruments in field-like conditions to offer a guideline for data analysis. They performed mobility and concentration comparison to reference instruments and also compared the ion spectrometers to each other. Asmi et al. (2009) and Gagné et al. (2010b) concluded that all the instruments agreed sufficiently in terms of particle number concentration and size. A repetition of the intercomparison also suggested that the cluster spectrometers sustained their measurement stability after operating approximately one year in different meteorological and geographical conditions.

\subsection{Measurement sites}

Comprehensive measurements with cluster spectrometers were conducted at twelve field sites around Europe (Fig. 1). Each one of these stations represents a particular environment. Table 1 lists all the sites from north to south, and highlights their special geographical features. The stations ranged from marine coastal sites to continental locations and those with high and low background aerosol concentrations. For example, the Hyytiälä field station is a rural site surrounded by a Scots pine dominated forest. Melpitz is a rural background site in Eastern Germany, and showed considerably higher levels of gaseous and particulate pollutants in comparison to Hyytiälä. Mace Head lies on the Atlantic coast of Ireland and has an immediate access to maritime air masses. On the other hand, Finokalia is located at the northern coast of Crete in the Mediterranean Sea. The three remote continental stations (Hohenpeissenberg, Jungfraujoch and Puy de Dôme) are mountain sites with a variable contribution of air masses originating from the boundary layer and free troposphere depending on the time of the day and the season. Each of the measurement sites is described in more detail in the following sections.

\subsubsection{Pallas}

The Pallas-Sodankylä GAW (Global Atmosphere Watch) station consists of two measurement stations in Finnish Lapland: Pallas and Sodankylä. Tropospheric air composition and related meteorological measurements are located at the Pallas station (Hatakka et al., 2003). The main measurement site Sammaltunturi (PAL, $67^{\circ} 58^{\prime} \mathrm{N} 24^{\circ} 06^{\prime} \mathrm{E}, 565 \mathrm{~m}$ a.s.l.), where the aerosol particle measurements are performed, is located on a treeless hill top about $300 \mathrm{~m}$ above the surrounding area. The area around Pallas is very sparsely populated and lies on the northern edge of the boreal forest zone. The Pallas station is a high-elevation, clean background site. New particle formation events have been observed frequently at Pallas (Komppula et al., 2003; Dal Maso et al., 2007). These 
Table 1. Short description of the measurement sites within the EUCAARI project relevant to this study. The location of the field site, site acronym, geographic coordinates, and site altitude in meters above sea level are shown. The site classification describes the geographical location and the pollutant gases as well as the aerosol particle concentrations at the site. The surroundings column characterizes the dominating landscape type surrounding the site.

\begin{tabular}{|c|c|c|c|c|c|}
\hline Measurement site & $\begin{array}{c}\text { Site } \\
\text { acronym }\end{array}$ & $\begin{array}{l}\text { Geographic } \\
\text { coordinates }\end{array}$ & $\begin{array}{l}\text { Altitude } \\
\text { (m a.s.l.) }\end{array}$ & Site classification & Surroundings \\
\hline Pallas, Finland & PAL & $67^{\circ} 58^{\prime} \mathrm{N}, 24^{\circ} 07^{\prime} \mathrm{E}$ & 560 & high-elevation, remote continental & boreal forest, tundra \\
\hline Vavihill, Sweden & VHL & $56^{\circ} 01^{\prime} \mathrm{N}, 13^{\circ} 09^{\prime} \mathrm{E}$ & 172 & rural background, continental & deciduous forest, field \\
\hline Mace Head, Ireland & MHD & $53^{\circ} 19^{\prime} \mathrm{N}, 09^{\circ} 53^{\prime} \mathrm{W}$ & 5 & marine background, coastal & Atlantic ocean, bare land \\
\hline Cabauw, Netherlands & CBW & $51^{\circ} 57^{\prime} \mathrm{N}, 04^{\circ} 53^{\prime} \mathrm{E}$ & 0 & clean marine, rural polluted & ocean, field, urban \\
\hline K-Puszta, Hungary & KPO & $46^{\circ} 58^{\prime} \mathrm{N}, 19^{\circ} 35^{\prime} \mathrm{E}$ & 125 & rural continental, background & field, deciduous forest \\
\hline Jungfraujoch, Switzerland & JFJ & $46^{\circ} 32^{\prime} \mathrm{N}, 07^{\circ} 57^{\prime} \mathrm{E}$ & 3580 & high altitude, background & mountain \\
\hline Puy de Dome, France & PDD & $45^{\circ} 42^{\prime} \mathrm{N}, 03^{\circ} 13^{\prime} \mathrm{E}$ & 1465 & high-elevation, background & forest, mountain \\
\hline San Pietro Capofiume, Italy & SPC & $44^{\circ} 37^{\prime} \mathrm{N}, 11^{\circ} 40^{\prime} \mathrm{E}$ & 11 & rural polluted, continental & field, suburban \\
\hline Finokalia, Greece & FKL & $35^{\circ} 20^{\prime} \mathrm{N}, 25^{\circ} 40^{\prime} \mathrm{E}$ & 250 & marine background, coastal & Mediterranean sea, dust \\
\hline
\end{tabular}

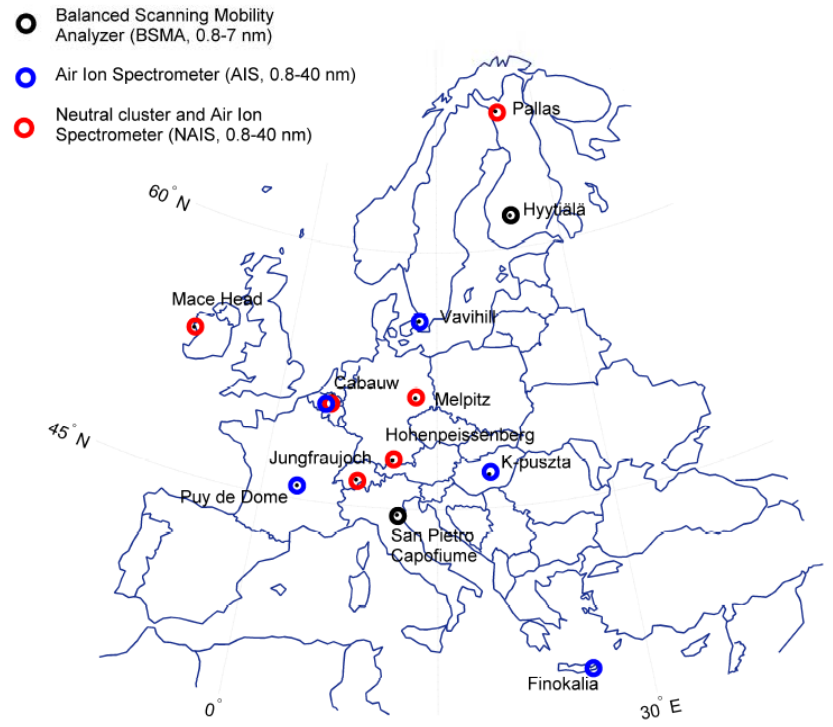

Fig. 1. Comprehensive field measurements were conducted at 12 field sites around Europe marked with a circle during March 2008May 2009 within the EUCAARI project. The colour of the circle refers to the instrument type used at the site as indicated in the upper left corner legend.

events have been connected to clean marine/polar air masses originating from the Arctic Ocean or the northern Atlantic (Komppula et al., 2003, 2006).

\subsubsection{Hyytiälä}

In Hyytiälä, the measurements were performed at the SMEAR II (Station for Measuring Forest EcosystemAtmosphere Relations II) station located in Southern Finland
(HTL, $61^{\circ} 51^{\prime} \mathrm{N} 24^{\circ} 17^{\prime} \mathrm{E}, 181 \mathrm{~m}$ a.s.l., Hari and Kulmala, 2005). The station is equipped with extensive facilities to measure forest ecosystem-atmosphere interactions continuously and comprehensively (Kulmala et al., 2001a). A rather homogeneous coniferous boreal forest surrounds this rural continental station. The forest emits biogenic volatile organic compounds (Hakola et al., 2003), which are precursors for low-volatile vapors contributing to aerosol formation and growth processes (e.g. Kulmala et al., 2001b; Tunved et al., 2006). New particle formation is frequently observed in this environment, especially in spring and autumn (Dal Maso et al., 2005).

\subsubsection{Vavihill}

In Vavihill, the measurements were performed at a joint EUCAARI, EUSAAR (European Supersites for Atmospheric Aerosol Research) and EMEP (European Monitoring and Evaluation Program, Co-operative programme for monitoring and evaluation of the long range transmission of air pollutants in Europe) network site in southern Sweden (VHL, $56^{\circ} 01^{\prime} \mathrm{N}, 13^{\circ} 09^{\prime} \mathrm{E}, 172 \mathrm{~m}$ a.s.l., Kristensson et al., 2008). Vavihill is a continental background site with no local sources of pollution. The immediate surroundings include a cattle field and beech forest. When winds are coming from north-west to north-east, the air masses are usually very clean. However, there are several densely populated areas nearby, such as Copenhagen (Denmark, 2 million inhabitants, $60 \mathrm{~km}$ southwest), Malmö (Sweden, 250000 inhabitants, $50 \mathrm{~km}$ south), and Helsingborg (Sweden, 100000 , $25 \mathrm{~km}$ west). There is intense ship traffic in the strait separating Sweden and Denmark, and Vavihill is also closeto the European continent in the south. 


\subsubsection{Mace Head}

The Mace Head atmospheric research station (MHD, $53^{\circ} 19^{\prime} \mathrm{N}, 9^{\circ} 54^{\prime} \mathrm{W}, 5 \mathrm{~m}$ a.s.1., O'Connor et al., 2008) is a Global Atmospheric Watch (GAW) super-site situated on the west coast of Ireland facing the North Atlantic Ocean. The station is located $100 \mathrm{~m}$ from the coastline surrounded by bare land (rocks, grass and peat bog), with no forest or trees in the surroundings. Few scattered single houses are located at the distance of $1 \mathrm{~km}$ or further. The nearest city (Galway, 80000 inhabitants) is located $60 \mathrm{~km}$ to the east/south-east of the station. The site is well exposed to clean marine westerly air masses associated with low pressure systems accounting for nearly $50 \%$ of occurrences. Pollution outbreaks are related to high pressure synoptic scale conditions bringing polluted air from the UK and continental Europe (Jennings et al., 2003). Coastal new particle formation is frequently observed at Mace Head (O’Dowd et al., 2002; Yoon et al., 2006).

\subsubsection{Cabauw}

The Cabauw site is located on a flat terrain in the centre of The Netherlands (CBW, 51 $57^{\prime} \mathrm{N} 4^{\circ} 53^{\prime} \mathrm{E}, 60 \mathrm{~m}$ a.s.l., van Ulden and Wieringa, 1996). The Cabauw Experimental Site for Atmospheric Research (CESAR) is the central point of experimental atmospheric research in The Netherlands. Cabauw is a part of several atmospheric observation networks, e.g. EMEP, EUSAAR, BSRN (Baseline Surface Radiation Network), GRUAN (GCOS Reference Upper Air Network) and a candidate GAW station. The rural area of Cabauw, situated at approximately $50 \mathrm{~km}$ from the North Sea, is surrounded by densely populated and industrialized areas. The enclosing conurbation has a population of over 10 million inhabitants and the heavily industrialized German Ruhr area is east of Cabauw. In contrast, in north of the Netherlands there is an open connection to the Atlantic Ocean and even the polar region via the North Sea. Therefore, both very clean maritime and highly-polluted air masses are observed at Cabauw (Crumeyrolle et al., 2010).

\subsubsection{Melpitz}

Melpitz is an atmospheric research station in Eastern Germany (MPZ, $51^{\circ} 32^{\prime} \mathrm{N} 12^{\circ} 54^{\prime} \mathrm{E}, 87 \mathrm{~m}$ a.s.l.). Melpitz is a part of several atmospheric observation networks: EMEP, EUSAAR and GUAN (German Ultrafine Aerosol Network; Birmili et al., 2009). The station is surrounded by flat grass lands, agricultural pastures and woodlands within several tens of kilometers, and no obstacles or larger sources of pollution lie within the immediate vicinity of the station. Within a European context, the observations at Melpitz are representative of a more anthropogenically influenced background of the European boundary layer (Putaud et al., 2004). Air mass analyses have shown that the aerosol in Melpitz is influenced by rather contrasting air masses, either of mar- itime origin (westerly winds), prevailing about $70 \%$ of the time, or of continental origin (easterly winds) (Birmili et al., 2001; Spindler et al., 2004; Engler et al., 2007). Birmili and Wiedensohler (2000) and Hamed et al. (2010) have suggested that in Melpitz, anthropogenic $\mathrm{SO}_{2}$, in conjunction with solar radiation as the driving force behind the oxidation of the precursors to condensable vapors, is the primary source of new particle formation events.

\subsubsection{Hohenpeissenberg}

The Hohenpeissenberg Meteorological Observatory (German Meteorological Service, DWD) is located on the Hohenpeissenberg mountain ( $\mathrm{HPB}, 47^{\circ} 48^{\prime} \mathrm{N} 11^{\circ} 0^{\prime} \mathrm{E}, 980 \mathrm{~m}$ a.s.l.) about $40 \mathrm{~km}$ north of the Alps in Southern Germany. It resides $300 \mathrm{~m}$ above the surrounding countryside. Except for a nearby village Hohenpeissenberg (778 $\mathrm{m}$ a.s.1.), the closer surroundings of the observatory are mainly forests and meadows. Hohenpeissenberg is a high-elevation background site. New particle formation has been investigated at the site since 1998 in relation to sulphuric acid and biogenic precursor gases (e.g. Birmili et al., 2003; Paasonen et al., 2009).

\subsubsection{K-puszta}

The K-puszta station (KPO, $46^{\circ} 58^{\prime} \mathrm{N} 19^{\circ} 33^{\prime} \mathrm{E}, 136 \mathrm{~m}$ a.s.l.) is a rural site on the Great Hungarian Plain about $15 \mathrm{~km}$ northwest from the nearest town Kecskemét (70000 inhabitants) and $80 \mathrm{~km}$ southeast of Budapest (1.7 million inhabitants). The station is located on a forest clearing; the surrounding forest contains both deciduous and coniferous trees (Horváth and Sutton, 1998). The site is exposed to polluted continental air masses associated with higher particulate matter and trace gas concentrations (Maenhaut et al., 2008). In contrast, the air masses from the northwest over the North Sea or the Atlantic Ocean transport colder, cleaner air over the K-puszta site. The station is a part of the GAW and EMEP networks and is one of the EUSAAR supersites. New particle formation is a frequent phenomenon in K-puszta; during the summer particle formation events are observed almost every day (Yli-Juuti et al., 2009).

\subsubsection{Jungfraujoch}

The high altitude research station of Jungfraujoch (JFJ, $46^{\circ} 32^{\prime} \mathrm{N} 7^{\circ} 59^{\prime} \mathrm{E}$ ) is located on an exposed anticline in the Swiss Alps at the altitude of $3580 \mathrm{~m}$. The station is regularly engulfed in clouds, $37 \%$ of the time based on a yearlong survey reported by Baltensperger et al. (1998). Due to its altitude and remote location, there is no influence of any significant anthropogenic pollution source. The aerosol loading at Jungfraujoch exhibits a strong seasonal cycle with a maximum in summer and minimum in winter (Weingartner et al., 1999). This is because in summer the site is influenced by injections of more polluted planetary boundary layer (PBL) air during afternoons in conjunction with high solar irradiation. 
In winter, as well as during summer nights, Jungfraujoch can be regarded as a representative site for the continental lower free troposphere. During the colder seasons (autumn, winter and spring) an increased number fraction of small particles $(10 \mathrm{~nm}<$ particle diamter $<18 \mathrm{~nm}$ ) is observed (Weingartner et al., 1999).

\subsubsection{Puy de Dome}

The research station is located at the summit of Puy de Dôme in the central mountains of France (PDD, $45^{\circ} 42^{\prime} \mathrm{N} 03^{\circ} 13^{\prime} \mathrm{E}$, $1465 \mathrm{~m}$ a.s.l.). The peak is more than a few hundred meters above the tree-line. The station is equipped with extensive facilities to measure aerosol cloud interactions (Sellegri et al., 2003), as well as physical, chemical and biological processes in clouds (Amato et al., 2007; Marinoni et al., 2004; Wobrock et al., 2001), both continuously and comprehensively. The site is at an intermediate altitude and the variability of the atmospheric composition is explained by a regular transition from free tropospheric/residual layer to boundary layer conditions. Variations of aerosol parameters at Puy de Dôme are due to i) cycles of the concentrations of particles in the boundary layer, ii) differences of the boundary layer dynamics and iii) enhanced photochemical processes during summer. New particle formation is frequently observed in this environment (Venzac et al., 2007).

\subsubsection{San Pietro Capofiume}

San Pietro Capofiume (SPC, $44^{\circ} 39^{\prime} \mathrm{N} 11^{\circ} 37^{\prime}$ E, $11 \mathrm{~m}$ a.s.l.) is located in a flat rural continental area in the eastern part of the Po Valley, in Northern Italy, between the cities of Bologna and Ferrara (roughly $40 \mathrm{~km}$ from both of the cities, 400000 and 100000 inhabitants, respectively). The Po Valley is a major pollution hotspot. However, the station is surrounded by vast crop fields with only a few local pollution point sources nearby. Therefore, SPC must be considered as a receptor site, in which the aerosol concentration and composition reflect the Po Valley regional background. New particle formation events have been observed at San Pietro Capofiume site since 2002 (Laaksonen et al., 2005). NPF is observed on about $36 \%$ of the days with maximum frequency between May and July (Hamed et al., 2007).

\subsubsection{Finokalia}

Finokalia (FKL, $35^{\circ} 24^{\prime} \mathrm{N} 25^{\circ} 60^{\prime} \mathrm{E}, 250 \mathrm{~m}$ a.s.l.) is a remote coastal station located in the southeast Mediterranean Sea on the island of Crete, Greece. The nearest large urban center is Heraklion with 150000 inhabitants $50 \mathrm{~km}$ west of Finokalia. The Finokalia station is located at the top of a hill at an elevation of $250 \mathrm{~m}$, facing the sea. There is no notable human activity in a range of approximately $15 \mathrm{~km}$ from the site (Mihalopoulos et al., 1997; Kouvarakis et al., 2000). Using back trajectory analysis, Pikridas et al. (2010) identified five source regions - Athens, Greece, continental Europe, Africa and marine - for particle matter observed in Finokalia. The station is equipped with instruments for continuous monitoring of chemical and optical properties of aerosols and trace gases.

\subsection{Instrumentation}

The Air Ion Spectrometer (AIS, Mirme et al., 2007) measures the mobility distributions of both negative and positive air ions simultaneously in the range between 3.2 and $0.0013 \mathrm{~cm}^{2} \mathrm{~V}^{-1} \mathrm{~s}^{-1}$, which corresponds to a mobility diameter range of $0.8-42 \mathrm{~nm}$. We apply the mobility diameter, i.e. Millikan diameter, when converting the measured mobility to particle diameter (see Mäkelä et al., 1996). The AIS consist of two parallel cylindrical Differential Mobility Analyzers (DMAs), one for classifying negative ions and the other for positive ions. The ions are simultaneously classified according to their electrical mobility and collected to electrically isolated sections. Each section has its own electrometer to measure the currents carried by the ions.

The Balanced Scanning Mobility Analyzer (BSMA, Tammet, 2006) measures the mobility distributions of small air ions and naturally charged aerosol particles of both negative and positive polarity. The mobility distribution is measured by scanning through the corresponding mobility range within $10 \mathrm{~s}$. The mobility range of the BSMA is 3.2$0.032 \mathrm{~cm}^{2} \mathrm{~V}^{-1} \mathrm{~s}^{-1}$, corresponding to the mobility diameter range of $0.8-8.0 \mathrm{~nm}$. The BSMA consists of two plate capacitors, one for each polarity, and a common electrical amplifier connected to a balanced bridge circuit.

Although the ion spectrometers detect freshly formed charged particles well below $1.2-2 \mathrm{~nm}$, which is the size range where most of the cluster activation takes place, the majority of these freshly formed particles are uncharged (Hõrrak et al., 2001; Kulmala et al., 2007; Manninen et al., $2009 \mathrm{~b})$. Therefore, measurements of neutral particles below $3 \mathrm{~nm}$ are necessary. The Neutral cluster and Air Ion Spectrometer (NAIS, Kulmala et al., 2007) is a modified version of the AIS instrument and includes several improvements. A controlled charging of the aerosol sample with a corona charger, together with electrical filtering of the corona charger ions, enables one to measure also the neutral aerosol particles. The mobility range of the NAIS is 3.2 $0.0013 \mathrm{~cm}^{2} \mathrm{~V}^{-1} \mathrm{~s}^{-1}$, which corresponds to a mobility diameter range of $0.8-42 \mathrm{~nm}$. However, the corona charger ions have a mobility range of $1.3-1.6 \mathrm{~cm}^{2} \mathrm{~V}^{-1} \mathrm{~s}^{-1}$, which results in the lower detection limit of approximately $2 \mathrm{~nm}$ (Asmi et al., 2009). Particles below this limit cannot be reliably distinguished from charger ions.

The dataset collected during the campaign with cluster mobility spectrometers contains number size distribution data of atmospheric charged and uncharged aerosol particles. The AIS and NAIS data was measured with a 5-minute time resolution and the BSMA determined the ion size distribution with a 10-min time resolution. During the continuous 
field measurements, the instruments were thoroughly cleaned at 2-3 month intervals due to deposition of particulate matter inside the instruments. The deposition of dirt onto the electrometer ring can deteriorate the signal-to-noise ratio of the electrometer. Also, when dirt is deposited onto the nets inside the venturi flow tubes (i.e. tubes with narrow slits for adjusting the volume flow), it causes the flow resistance to increase, which consequently decreases the volume flow through the venturi tubes and affects the mobility classification. The data with high noise levels and/or low volume flows were classified as bad data, and were excluded from the analysis. The diagnostic data were used to monitor the instrument performance during the field measurements and afterwards to explore the quality of the measured data.

Supporting aerosol particle instruments like the Differential Mobility Particle Sizer (DMPS) and the Scanning Mobility Particle Sizer (SMPS) were used at EUCAARI field sites to get information about the background aerosol particle population. Their typical measuring size range covered total particle number size distribution from 3 to $800 \mathrm{~nm}$ (Table 2).

\subsection{Calculating particle formation and growth rates}

The rate at which the newly formed aerosol population grows can be determined from the measured number size distributions (Hirsikko et al., 2005). A normal distribution function was fitted into the time series of the particle concentrations in a certain size bin. After determining the moment corresponding to the maximum concentration in each of the size bins, the growth rates (GR) were obtained by a linear leastsquare fit through the data points in the selected size classes. For the ion data, both polarities were analyzed separately. The charged particle growth rates were calculated for three diameter classes $(1.5-3 \mathrm{~nm}, 3-7 \mathrm{~nm}$ and $7-20 \mathrm{~nm})$ from AIS data. In case of BSMA measurements, only the two first size classes were used. GR calculations were possible only during particle formation events, when we observed high enough concentrations of ions. These calculated growth rates (Hirsikko et al., 2005) can deviate from the real atmospheric growth rates by up to the factor two because of observational uncertainties.

The total particle formation rate at $2 \mathrm{~nm}\left(J_{2}\right)$, i.e. the flux of particles into the $2-3 \mathrm{~nm}$ size range, can be calculated from the total particle concentrations measured in the size range of $2-3 \mathrm{~nm}, N_{2-3}$ by taking into account the losses due to coagulation scavenging to the larger pre-existing particles, as well as the growth out of the $2-3 \mathrm{~nm}$ size range (Kulmala et al., 2007, supporting information). The following formula is obtained for the total particle formation rate

$J_{2}=\frac{\mathrm{d} N_{2-3}}{\mathrm{~d} t}+\operatorname{Coag} S_{2} \cdot N_{2-3}+\frac{1}{1 \mathrm{~nm}} \mathrm{GR}_{3} N_{2-3}$,

Here the time derivative of $\mathrm{N}_{2-3}$ is obtained directly from the NAIS measurements, coagulation scavenging rate, $\operatorname{Coag} S_{2}$, is calculated from the background particle size distribution measured by the DMPS or the SMPS, and the particle growth in the size range $2-3 \mathrm{~nm}, \mathrm{GR}_{3}$, is calculated from the ion data.

In the case of charged particles, the losses due to ion-ion recombination and sources due to charging of 2-3 nm neutral particles need to be taken into account. The formation rate of $2-3 \mathrm{~nm}$ charged particles can thus be expressed as

$$
\begin{aligned}
J_{2}^{ \pm}= & \frac{\mathrm{d} N_{2-3}^{ \pm}}{\mathrm{d} t}+\operatorname{Coag} S_{2} \cdot N_{2-3}^{ \pm}+\frac{1}{1 \mathrm{~nm}} \mathrm{GR}_{3} N_{2-3}^{ \pm} \\
& +\alpha \cdot N_{2-3}^{ \pm} N_{<3}^{\mp}-\beta \cdot N_{2-3} N_{<2}^{ \pm},
\end{aligned}
$$

where $N_{2-3}^{ \pm}$refers to the $2-3 \mathrm{~nm}$ charged particle concentration, $N_{<3}^{\mp}$ the sub-3 $\mathrm{nm}$ charged particle concentration of the opposite polarity and $N_{<2}^{ \pm}$is the ion concentration below $2 \mathrm{~nm}$. The ion-ion recombination coefficient, $\alpha$, and ionneutral attachment coefficient, $\beta$, were assumed to be equal to $1.6 \times 10^{-6} \mathrm{~cm}^{3} \mathrm{~s}^{-1}$ and $0.01 \times 10^{-6} \mathrm{~cm}^{3} \mathrm{~s}^{-1}$, respectively (e.g. Tammet and Kulmala, 2005). The ion concentrations were obtained from the AIS or the BSMA number size distributions. Suggestive uncertainty estimations for the formation and growth rate calculations are presented in Manninen et al. (2009a). Both the formation and growth rate of 2 to $3 \mathrm{~nm}$ particles might be approximately a factor of 2 lower or higher than the values estimated here due to uncertainties in measurements and data analysis.

\section{Results and discussion}

Our main focus was to investigate atmospheric nucleation and initial steps of growth in various environments. First, the quality of measured data was ensured, and all the available days were classified and grouped into different nucleation event classes (Dal Maso et al., 2005). Second, the particle growth and formation rates were calculated for new particle formation (NPF) events in order to characterize the processes leading to nucleation. Third, the contribution of ions to particle formation was investigated. By comparing the nucleation parameters at different sites, we obtained information about the spatial and temporal variation of the new particle formation events. The spatial extent of nucleation events connecting the NPF events observed at different sites (e.g. Komppula et al., 2006) is excluded from this study.

\subsection{Event statistics}

New particle formation events were observed to be frequent during the atmospheric measurements within the EUCAARI project at all of the sites. An exemplary time series of consecutive new particle formation events at Melpitz site is presented in Fig. 2. It shows a time series of total particle size distribution measured by the NAIS in the particle mode during 10-16 April 2009, in Melpitz, Germany, along with the corresponding negative and positive ion size distribution 
Table 2. Aerosol instrumentation, measuring range and the measurement period during the EUCAARI project at each measurement site. The AIS and the BSMA measured ion number size distributions, whereas the NAIS measured both ion and total particle number size distributions. Supporting aerosol instrumentation - the DMPS and the SMPS - measured total particle number size distributions.

\begin{tabular}{lccc}
\hline Measurement site & Mobility spectrometer & Measured size range (nm) & Measurement period \\
\hline Pallas, Finland & NAIS & $0.8 / 2.0-42$ & 23 Apr 2008-7 Apr 2009 \\
Hyytiälä, Finland & BSMA & $0.8-7.6$ & 1 Mar 2008-31 Apr 2009 \\
Vavihill, Sweden & AIS & $0.8-42$ & 23 Apr 2008-25 Feb 2009 \\
Mace Head, Ireland & NAIS & $0.8 / 2.0-42$ & 13 Jun 2008-7 May 2009 \\
Cabauw, Netherlands & NAIS, AIS & $0.8 / 2.0-42$ & 16 Apr 2008-31 Mar 2009 \\
Melpitz, Germany & NAIS & $0.8 / 2.0-42$ & 30 Apr 2008-19 Apr 2009 \\
Hohenpeissenberg, Germany & NAIS & $0.8 / 2.0-42$ & 6 Mar 2008-26 Feb 2009 \\
K-Puszta, Hungary & AIS & $0.8-42$ & 10 Mar 2008-26 Feb 2009 \\
Jungfraujoch, Switzerland & AIS & $0.8-42$ & 8 Apr 2008-20 Apr 2009 \\
Puy de Dome, France & NAIS & $0.8 / 2.0-42$ & 2 Apr 2008-5 May 2009 \\
San Pietro Capofiume, Italy & BSMA & $0.8-7.6$ & 12 Mar 2008-31 Oct 2008 \\
Finokalia, Greece & AIS & $0.8-42$ & 3 Apr 2008-14 Apr 2009 \\
\hline Measurement site & Supporting instrument & Measured size range (nm) & Measurement period \\
\hline Pallas, Finland & DMPS & $7-500$ & 1 Mar 2008-30 Apr 2009 \\
Hyytï̈lä, Finland & DMPS & $3-1000$ & 1 Mar 2008-30 Apr 2009 \\
Vavihill, Sweden & DMPS & $3-850$ & 20 Mar 2008-31 Dec 2008 \\
Mace Head, Ireland & SMPS & $3-1000$ & 12 Jun 2008-30 Apr 2009 \\
Cabauw, Netherlands & SMPS & $9-516$ & 1 Apr 2008-31 Mar 2009 \\
Melpitz, Germany & DMPS & $3-800$ & 1 Mar 2008-30 Apr 2009 \\
Hohenpeissenberg, Germany & SMPS & $10-900$ & 13 Mar 2008-13 Apr 2009 \\
K-Puszta, Hungary & DMPS & $6-800$ & 8 May 2008-12 Mar 2009 \\
Jungfraujoch, Switzerland & SMPS & $13-800$ & 1 Mar 2008-7 Mar 2009 \\
Puy de Dome, France & SMPS & $3-1000$ & 3 Apr 2008-18 Mar 2009 \\
San Pietro Capofiume, Italy & DMPS & $3-600$ & 16 Mar 2008-31 Oct 2008 \\
Finokalia, Greece & SMPS & $9-900$ & 5 Jun 2008-14 Apr 2009 \\
\hline & & & \\
\hline
\end{tabular}

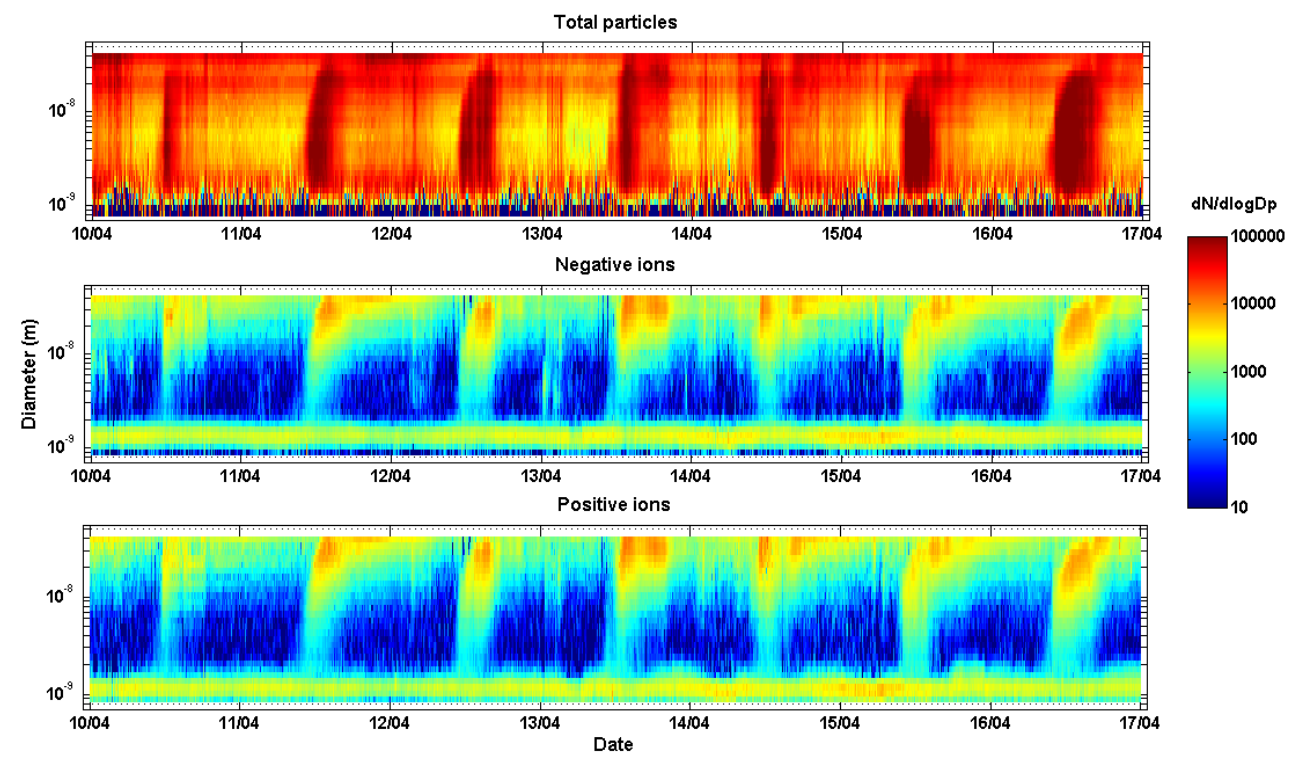

Fig. 2. Particle and ion number size distribution measured with the NAIS on seven consecutive new particle formation event days on 10-16 April 2009 in Melpitz, Germany. 
measured by the NAIS in the ion mode. These seven consecutive days had clear indications of new particle formation and growth in the smallest size range. The time series of negative and positive ion size distribution were similar to that of the total particle size distribution, even though the ion concentrations were about two orders of magnitude smaller than total particle concentrations.

\subsubsection{Frequency of new particle formation events}

The classification of available measurement days into event, non-event and undefined days was performed according to methods introduced by Dal Maso et al. (2005) and Hirsikko et al. (2007). A day was classified as an event day when new particle formation and growth were observed. Likewise, days without a clear indication of NPF were grouped to non-event days. Finally, the days which did not fulfill the aforementioned criteria were categorized as undefined. The classification criteria are explained in more detail in Appendix Table A1 and in Dal Maso et al. (2005). The classification was performed visually from the ion data measured by the AIS, NAIS and BSMA using daily contour plots of the size distribution such as those shown in Fig. 2. Both polarities were classified separately. In the final classification format, the day was classified as an event day if particle formation was detected in either or both of the polarities (negative and positive), and as a non-event day if it was a non-event day for both polarities. All the other days were classified as undefined days.

The total number of event days observed at each station during the field measurement period varied from site to site, ranging from 31 events in Pallas, Finland, to 162 events in K-puszta, Hungary. The total number of events was dependent on both the environment (the regional atmospheric conditions around the measurement site) and the length of the measurement period. Figure 3 a shows the fraction of event days at each site when the number of event days was divided by the number of all available days. The observed fraction of event days varied between $57 \%$ in Melpitz, Germany, and $21 \%$ in Pallas, Finland. Several long-term, continuous measurements of nucleation mode particles have shown that the number of particle formation event days may vary considerably from year to year (e.g. Dal Maso et al., 2005, 2007; Kulmala et al., 2010; Hamed et al., 2010). In Hyytiälä, Finland, for example, we observed particle formation on $24 \%$ of all days, whereas within the last 13 years the inter-annual variation in the fraction of events ranges from $18 \%$ to $33 \%$ with median of $23 \%$ (Kulmala et al., 2010).

Figure $3 b$ shows the ratio of the event days to the number of days with no clear indications of particle formation and growth. This ratio was larger than 2 in Melpitz and above unity in Mace Head, K-Puszta, Jungfraujoch, San Pietro Capofiume Puy de Dôme, Hohenpeissenberg and Hyytiälä. On the contrary, the ratio was below unity in Cabauw, Finokalia, Pallas and Vavihill, implying that the majority of

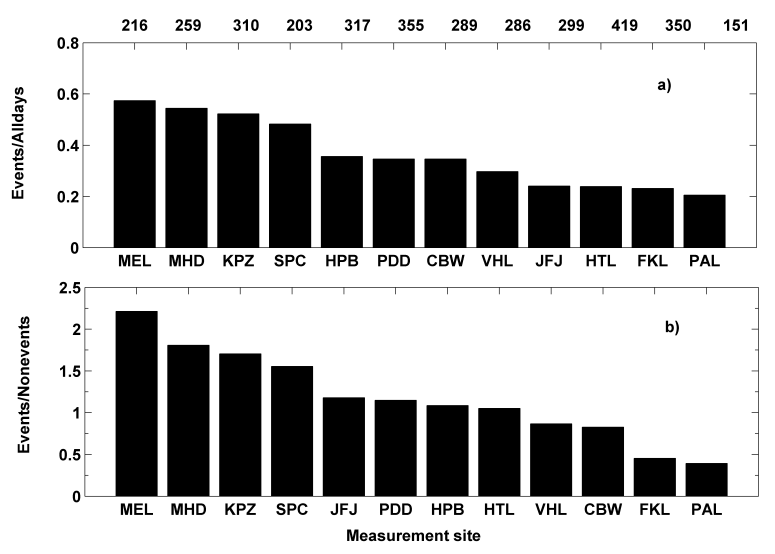

Fig. 3. (a) The fraction of NPF event days relative to the number of all the days and (b) event to non-event day number ratio on each measurement site during the EUCAARI field measurements 2008-2009. The site name abbreviations are listed in Table 1. The numbers above the figure refer to the number of days included in the analysis.

the classified days had no indication of particle formation in those sites. The highest event to non-event day ratios were observed mostly in rural central Europe. Mace Head, the coastal site, was an exception.

\subsubsection{Seasonal cycle of the event frequency}

Seasonal cycles were observed in the NPF event frequency. The monthly median of the particle formation and growth event distribution for all the sites is presented in Fig. 4a, from which we can see that the frequency of event and non-event days follow roughly opposite seasonal patterns. The number of NPF event days has a maximum in May and the nonevent days around December-January. On the other hand, the undefined days had no clear seasonal cycle. The number of the undefined days had two indistinct maxima at the same time as the maxima for the events and non-events were observed. The monthly event to non-event ratio had a clear maximum during late spring and a minimum during early winter (Fig. 4b). A high event frequency in spring time is consistent with many earlier studies (e.g. Hõrrak et al., 1998; Birmili and Wiedensohler, 2000; Birmili et al., 2003; Dal Maso et al., 2005, 2007; Vana et al., 2008; Hamed et al., 2010), suggesting a connection of new particle formation to the presence of solar radiation and onset of biogenic activity.

However, the monthly event distribution varied from one station to another (see Appendix, Figs. A1-A12), as is expected due to the influence of different meteorological and geographical conditions between the stations. We distinguished four groups according to the seasonal cycle of NPF event frequency, hereafter referred with roman numerals IIV. In Hyytiälä, Vavihill, Cabauw and Jungfraujoch (group 

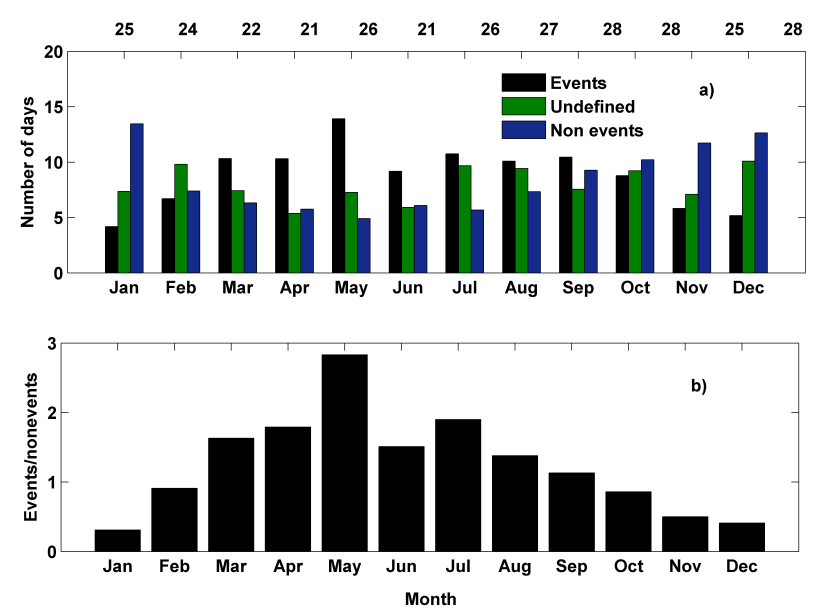

Fig. 4. (a) The median monthly number of particle formation event, undefined and non-event days, and (b) the median monthly event to non-event day ratio for all the sites from April 2008 to April 2009 within the EUCAARI project. The numbers above the top figure refer to the median number of days included in the analysis. These numbers are the average values observed at all the twelve field sites.

I sites), the number of nucleation events were highest in May-June and lowest in December-January. These four sites matched well with the median monthly NPF event distribution for all the sites illustrated in Fig. 4b. In Mace Head, Melpitz and K-Puszta (group II sites), the seasonal cycle followed the same pattern as in group I sites, but generally the total number of events was higher. In K-Puszta, the total number of new particle formation events was the highest of the investigated stations.

The most non-event days were seen in Finokalia (group III site) on a Mediterranean island. In Finokalia, the new particle formation events showed a maximum in winter and a minimum in summer. In our study, Pallas, Hohenpeissenberg, Puy de Dôme and San Pierto Capofiume were group IV sites, with no clear seasonal pattern in the event frequency. Birmili et al. (2003) reported frequent observations of the particle formation during winter months in Hohenpeissenberg but, due to the shortness of the campaign, this was not identified as a characteristic feature of the measurement site itself. Boulon et al. (2010a) reported that at Puy de Dôme the NPF events are most frequent during the warm season due to a greater influence of the boundary layer, which reaches the site most frequently during summer.

At Jungfraujoch, a lot of days were categorized as undefined (see Fig. A9), and the number of nucleation events was at its highest in May-June. Boulon et al. (2010b) observed that nucleation at the JFJ was less frequent during winter and promoted in air masses rich in volatile organic compounds (VOC). They also observed that clouds inhibited the occurrence of NPF events. During winter at Jungfraujoch, less VOC's are uplifted from lower altitudes and oxidized by pho- tochemistry and more clouds are formed at the station, which may explain the lower frequency of NPF events. However, Weingartner et al. (1999) suggested that new particle formation events at JFJ are most frequent in winter. We speculate that this is related to "wind/snow-induced events" which are mentioned later.

\subsubsection{Different event types}

A closer look at the time series of the particle formation, like the time series illustrated in Figs. 2 and 5, revealed that the nucleation bursts are almost exclusively observed during daytime and mostly starting before noon. Based on the visual shape of the time series of the number size distributions, several nucleation event types have been characterized (Dal Maso et al., 2005; Hirsikko et al., 2007; Vana et al., 2008; Yli-Juuti et al., 2009). The classical "banana" events (Fig. 5a-b, e) are typically observed at sites where NPF occurs over a geographically large area, whereas other nucleation event types (Fig. 5c-d, f) are indicative of more local NPF. Especially, the coastal areas are somewhat different from other places around Europe from the point of view of NPF (Vana et al., 2008).

The coastal NPF events at Mace Head occur typically during a low tide when the algae are exposed to sunlight leading to biogenic emissions of iodine vapors (Hoffmann et al., 2001; O'Dowd and Hoffmann, 2005). Particularly in Mace Head many different types of events were observed, including the "apple" (Fig. 5c) and "bump" (Fig. 5d) events in addition to the "banana" events (e.g. Vana et al., 2008). The "apple" and "bump" events at Mace Head result from a combination of inhomogeneities of the sea weed fields (due to the fragmented shape of coastal areas) and variations in the wind direction over the field (Sellegri et al., 2005). Typical "banana" events require that the site is exposed to relatively homogenous air masses over several hours. During the "apple" type events the source of nucleating and condensing vapors is confined to a relatively small area close to the measurement site, so that only particles grown to a certain size will be detected. A "bump" event occurs, when particle formation appears to be initiated by activation of cluster ions but the source of condensing vapors is too limited to result in a substantial growth of newly formed particles.

At the high-elevation sites (Pallas, Jungfraujoch and Puy de Dôme), we observed frequently a yet unexplained particle formation burst type (Fig. 5f), during which the concentrations of intermediate ions increased rapidly to very high levels, but no growth from cluster sizes were observed. Virkkula et al. (2007) reported the first observation of this type of a event at the Antarctic research station, Aboa. They established that these small air ion bursts were associated with high wind velocities and snow storms, and called these events "wind/snow-induced events". Since this phenomenon is not necessarily related to the atmospheric nucleation, we classified the days with wind-induced effects as undefined days. 

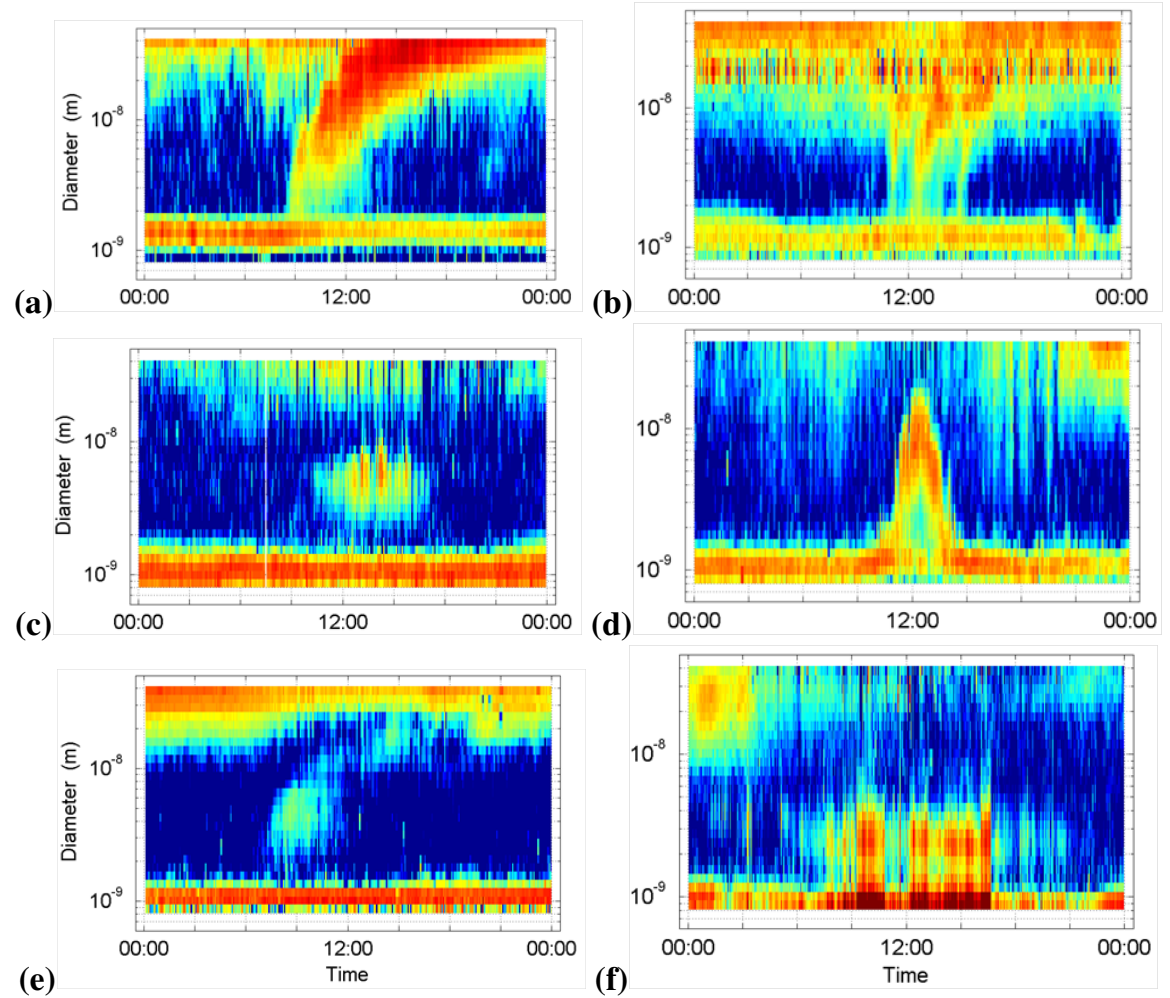

Fig. 5. Typical ion number size distribution measured with the cluster spectrometer in different environments (a) "banana" type event in Melpitz on 7 May 2008, (b) "banana" in Cabauw on 30 April 2008, (c) "apple" in Mace Head on 20 July 2008, (d) "bump" in Mace Head on 11 February 2009, (e) "banana” Finokalia on 20 March 2009 and (f) "wind-induced” event in Jungfraujoch on 28 November 2008.

This explains partly the high number of undefined days in Pallas, Jungfraujoch and Puy de Dôme. Occasional "bump" type events seemed to be characteristic for high-elevation sites.

\subsection{Particle formation and growth rates}

In order to investigate the amount of atmospheric vapors condensing to the particles in different environments, the growth rates of freshly formed particles were calculated according to a method outlined by Hirsikko et al. (2005). Only event classes Ia and Ib were included in the analysis. We calculated the growth rates from ion data for three size ranges $(1.5-3 \mathrm{~nm}, 3-7 \mathrm{~nm}$ and $7-20 \mathrm{~nm})$ for both polarities separately (Fig. 6). In case of BSMA measurements in Hyytiälä and San Pietro Capofiume, we calculated the GR for 7-20 nm particles from DMPS data. The median growth rate for all the sites in the $1.5-3 \mathrm{~nm}$ size range was $2.8 \mathrm{~nm} \mathrm{~h}^{-1}$ and it varied from $1.6 \mathrm{~nm} \mathrm{~h}^{-1}$ (SPC) to $4.8 \mathrm{~nm} \mathrm{~h}^{-1}$ (HPB). The corresponding values for the $3-7 \mathrm{~nm}$ size range was $4.3 \mathrm{~nm} / \mathrm{h}$, varying from $2.2 \mathrm{~nm} \mathrm{~h}^{-1}$ (PDD) to $7.2 \mathrm{~nm} \mathrm{~h}^{-1}$ (JFJ) and for the $7-20 \mathrm{~nm}$ size range $5.4 \mathrm{~nm} \mathrm{~h}^{-1}$, varying from $3.6 \mathrm{~nm} \mathrm{~h}^{-1}$ (HTL) to $6.8 \mathrm{~nm} \mathrm{~h}^{-1}(\mathrm{JFJ})$. The seasonal behavior of the growth rates in the different environments was not investigated due to the small amount of available days.
The median growth rates of $1.5-3 \mathrm{~nm}$ particles were typically smaller than the corresponding values of larger particles (Fig. 6). In other words, the larger the particles, the larger the measured growth rate was. This holds true for nine of the sites. The three exceptions were Pallas, Mace Head and Hohenpeissenberg, probably due to inhomogeneities in the sources of condensable vapors (at MHD inhomogeneity of the sea weed fields, and at the two high altitude sites the boundary layer dynamics). The size-dependency of the particle growth rates is consistent with earlier observations from Hyytiälä (Kulmala et al., 2004b; Hirsikko et al., 2005; Manninen et al., 2009a), Tumbarumba in Australia (Suni et al., 2008) and K-puszta (Yli-Juuti et al., 2009). The sizedependency suggests that there could be different condensing vapors participating in the growth of different-size particles depending on their saturation vapor pressures (e.g. Kulmala et al., 2004a). The particle growth might also vary with the time of day due to changing concentrations of condensing vapors during the growth process (e.g. Yli-Juuti et al., 2009).

Typically, the highest growth rates were observed at the sites with the strongest and the most frequent nucleation events. These sites (e.g. Cabauw, Mace Head and Hohenpeissenberg) seem to have enough nucleating and condensing vapors for frequent new particle formation. We compared our growth rate estimations with other studies (see Kulmala et 

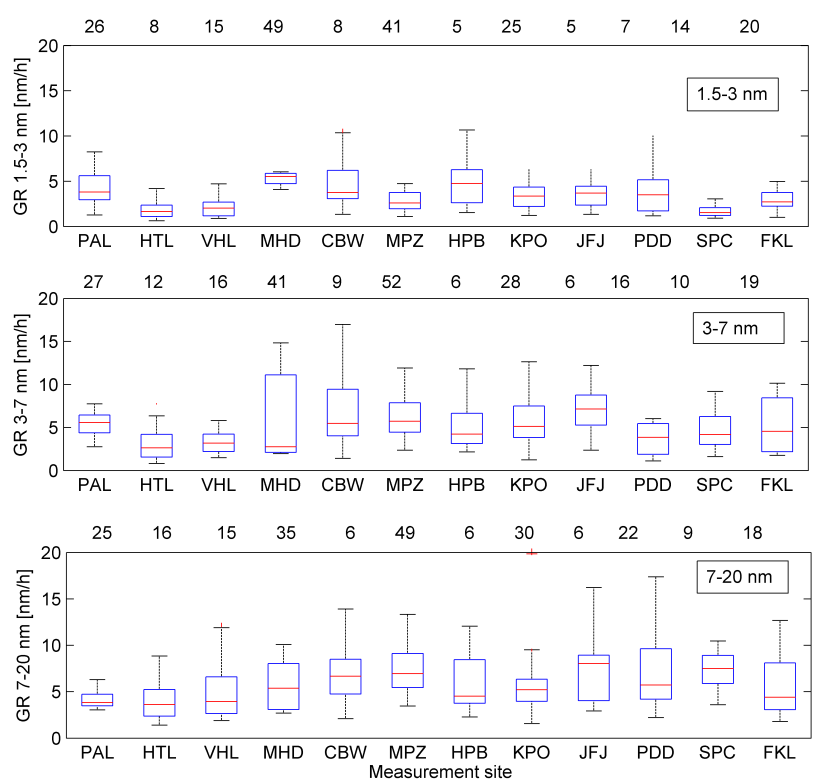

Fig. 6. Growth rates in three size ranges during all observed NPF events at different field sites in 2008-2009. The red lines show the medians, the boxes indicate the 25- and 75-percentiles, and the error bars the 5- and 95-percentiles. The numbers above the subplots refer to the number of days included in the analysis.

al., 2004c, and references therein), as well as with the recent studies conducted in Po-Valley, Italy (Hamed et al., 2007), Antarctica (Virkkula et al., 2007), Tumbarumba, Australia (Suni et al., 2008), Mexico City (Iida et al., 2008) and South Africa (Laakso et al., 2008). The growth rates observed in this study corresponded well with those measured in other continental background areas. Growth rates observed in polluted urban areas, such as Mexico City $\left(15-40 \mathrm{~nm} \mathrm{~h}^{-1}\right.$; Iida et al., 2008) or South Africa (3-21 $\mathrm{nm} \mathrm{h}^{-1}$; Laakso et al., 2008), were significantly higher.

The calculated charged and total particle formation rates at $2 \mathrm{~nm}$ for the different measurement sites are presented in Fig. 7 and summarized in Table 3 with some additional information. The formation rates were not calculated for the days on which the DMPS/SMPS data was missing as the coagulation sinks could not be accounted for $J_{2}$ 's. The calculations of total particle formation rates were possible only for the sites with the NAIS measurements. In K-puszta, the negative ion formation rates were missing due to malfunction of the instrument in the negative polarity. The formation rates of charged particles varied somewhat from day to day at all the sites, whereas the corresponding site-average formation rates were within a factor 2-3 from each other. Contrary to this, the site-average formation rates of total $2 \mathrm{~nm}$ particles varied by more than an order of magnitude between the different sites. The day-to-day variability of the total particle formation rate was typically higher at sites with larger average values of $J_{2}$.
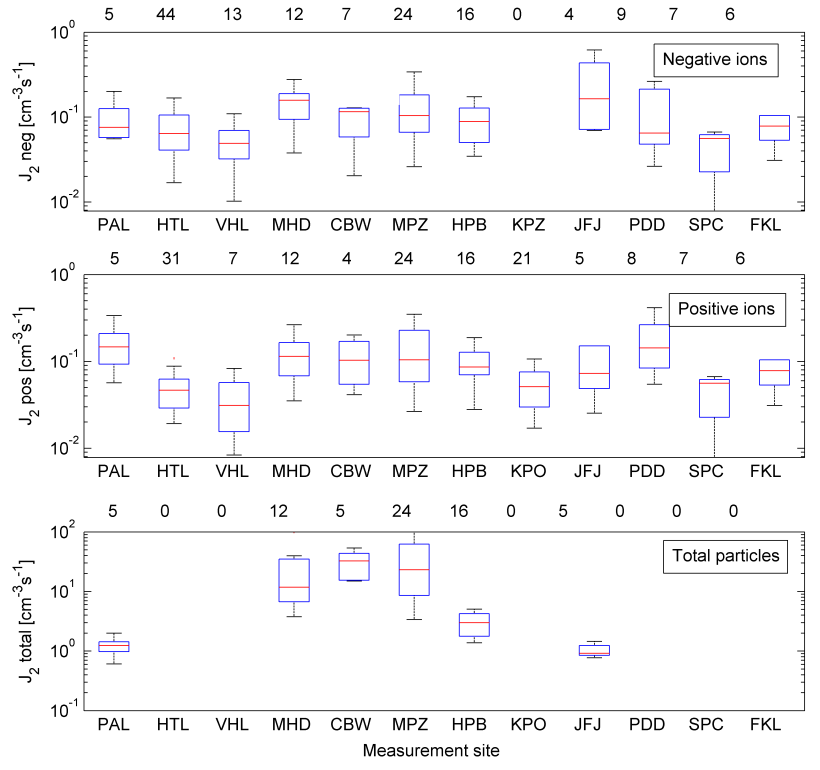

Fig. 7. Negative and positive ion and total particle formation rates during all the observed NPF events at different field sites in 20082009. The red lines show the medians, the boxes indicate the 25 and 75-percentiles, and the error bars the 5- and 95-percentiles. The numbers above the subplots refer to the number of NPF event days included in the analysis.

A high pre-existing particle surface area, i.e. a large condensation and coagulation sink, has traditionally been thought to suppress new particle formation (Weber et al., 1996; Kerminen et al., 2004; Kuang et al., 2010). The condensation sinks for all the sites were calculated from the particle size distributions measured with the DMPS/SMPS (Kulmala et al., 2001b). In our study, no relation between the values of condensation sink (CS) and the strength and frequency of new particle formation events between the different sites were observed. In many of the sites, however, nucleation was clearly preferred at lower values of CS (Table 3 ).

\subsection{Contribution of ions to total particle formation}

In case of parallel ion and neutral cluster measurements, we estimated the contribution of ions to the particle formation (i.e. the ion-induced fraction). According to the method described by Manninen et al. (2009a), the total nucleation rate can be expressed as the sum of neutral and ion-induced nucleation rates. In this study, ion-ion recombination was excluded from the neutral particle formation. Therefore, we calculated the ion-induced fraction, and not the ion-mediated nucleation fraction.

Figure 8 shows the contribution of ion-induced nucleation to the total nucleation rate, as measured using the NAIS at the six field sites (Pallas, Hyytiälä, Mace Head, Cabauw, Melpitz, Hohenpeissenberg and Jungfraujoch). The contribution of ion-induced nucleation to total particle formation at $2 \mathrm{~nm}$ 
Table 3. Summary of the median particle formation event characteristics on the twelve EUCAARI sites. First the fraction of event days of all available days for analysis, GR is the growth rate in $1.5-3 \mathrm{~nm}$ size range, $J_{2}^{\text {ion }}$ ion formation rate at $2 \mathrm{~nm}$ and $J_{2}^{\text {tot }}$ is the corresponding total particle formation rate during an event. $\mathrm{CS}_{\text {events }}$ is the condensation sink during the events and $\mathrm{CS}_{\text {non-events }}$ is the condensation sink for the non-event days.

\begin{tabular}{lcccccc}
\hline & $\begin{array}{c}\text { Fraction of } \\
\text { events }(\%)\end{array}$ & $\begin{array}{c}\text { GR 1-3 nm } \\
\left(\mathrm{nm} \mathrm{h}^{-1}\right)\end{array}$ & $\begin{array}{c}J_{2}^{\text {ion }} \text { neg/pos } \\
\left(\mathrm{cm}^{-3} \mathrm{~s}^{-1}\right)\end{array}$ & $\begin{array}{c}J_{2}^{\text {tot }} \\
\left(\mathrm{cm}^{-3} \mathrm{~s}^{-1}\right)\end{array}$ & $\begin{array}{c}\mathrm{CS}_{\text {events }} \\
\left(10^{-3} \mathrm{~s}^{-1}\right)\end{array}$ & $\begin{array}{c}\mathrm{CS}_{\text {non-events }} \\
\left(10^{-3} \mathrm{~s}^{-1}\right)\end{array}$ \\
\hline Pallas & 21 & 3.8 & $0.08 / 0.15$ & 1.2 & 0.63 & 0.53 \\
Hyytiälä & 24 & 1.6 & $0.06 / 0.05$ & $0.7^{\mathrm{a}}$ & 1.4 & 2.7 \\
Vavihill & 30 & 2.0 & $0.05 / 0.03$ & - & 3.4 & 5.0 \\
Mace Head & 54 & 5.5 & $0.16 / 0.11$ & 11.8 & 0.64 & 1.0 \\
Cabauw & 35 & 3.8 & $0.12 / 0.10$ & 32.4 & 2.9 & 6.7 \\
Melpitz & 57 & 2.6 & $0.10 / 0.10$ & 23.1 & 8.4 & 9.6 \\
Hohenpeissenberg & 36 & 4.8 & $0.09 / 0.09$ & 3.0 & 4.1 & 7.5 \\
K-Puszta & 52 & 3.6 & -10.05 & - & 6.6 & 13 \\
Jungfraujoch & 24 & 3.7 & $0.16 / 0.07$ & 0.9 & 0.59 & 0.49 \\
Puy de Dome & 35 & 3.5 & $0.06 / 014$ & - & 4.1 & 3.9 \\
San Pietro Capofiume & 48 & 1.5 & $0.06 / 0.06$ & - & 4.4 & 5.3 \\
Finokalia & 23 & 2.7 & $0.08 / 0.02$ & - & 4.2 & 8.3 \\
\hline
\end{tabular}

a Manninen et al. (2009a)

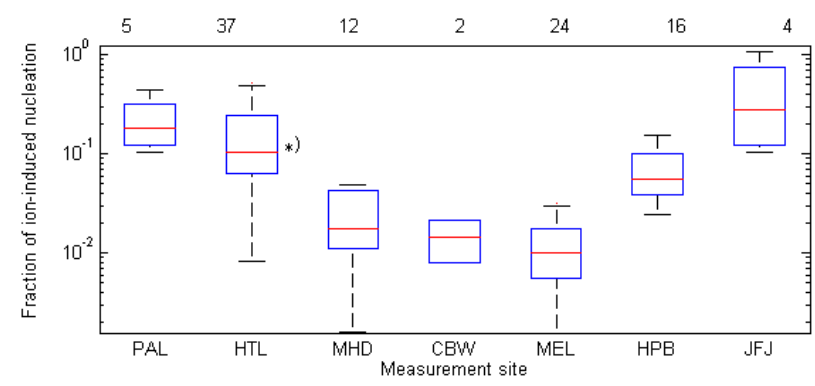

Fig. 8. Fraction of ion-induced nucleation according to formation rate calculations. These analyses include the observed NPF events at different field sites with the NAIS instruments during the EUCAARI project. The red lines show the medians, the boxes indicate the 25- and 75-percentiles, and the error bars the 5- and 95percentiles. The numbers above the subplots refer to the number of NPF event days included in the analysis. * Manninen et al. (2009a).

was typically in the range of $1-30 \%$. When comparing different sites, the contribution of ion-induced nucleation to total nucleation increased with the decreasing total formation rate of $2 \mathrm{~nm}$ particles, being the highest in Pallas and Junfraujoch. A summary of the contribution of ion-induced nucleation to atmospheric aerosol formation in this and some other studies is presented in Table 4. Excluding Jungfraujoch and Pallas, the contribution appears to be, on average, less than $10 \%$ in the continental boundary layer.

A comparison of charged and total particle formation rates during events is presented in Fig. 9 for five measurement sites. The figure presents the median diurnal behaviour of both negative and positive ion and total particle formation rates during all the event days from years 2008-2009. In Mace Head and Melpitz, the formation of charged $2 \mathrm{~nm}$ particles started earlier than that of neutral $2 \mathrm{~nm}$ particles, whereas negatively and positively charged $2 \mathrm{~nm}$ particles started to be formed at about the same time. A similar pattern has been observed earlier in Hyytiälä (Manninen et al., 2009a). Contrary to this, no different timing between formation of charged and neutral $2 \mathrm{~nm}$ particle could be observed in Cabauw, Hohenpeissenberg or Jungfraujoch. A possible explanation for the earlier formation of charged $2 \mathrm{~nm}$ particles, as compared with neutral ones, in some of the sites might be the preferential activation of charged cluster over neutral ones when the concentration of nucleating/condensing vapors is increasing during the morning. Such a phenomenon has been confirmed in laboratory experiments (Winkler et al., 2008), but requires that the principal particle formation route is the activation of pre-existing clusters (Kulmala et al., 2006). Another possibility is that there are multiple pathways for neutral $2 \mathrm{~nm}$ particle formation, and that some of them require higher precursor vapor concentrations than the charged particle formation. Analyzing the different timings of the formation of charged and neutral particle clearly deserves further attention.

\section{Conclusions}

Comprehensive atmospheric cluster and particle measurements were performed within the EUCAARI project (Kulmala et al., 2009; Kerminen et al., 2010). Our experiments have been, to our knowledge, the most comprehensive effort to experimentally characterize nucleation and growth 
Table 4. The observed fraction of ion-induced nucleation (IIN) from total particle formation in various environments. The fraction reported by Manninen et al. (2009a) includes also the contribution of ion-ion recombination to IIN.

\begin{tabular}{lccl}
\hline Measurement site & Instrument & IIN fraction & Reference \\
\hline Boulder & IGMA* & $0.5 \%$ & Iida et al. (2006) \\
Cabauw & NAIS & $1.5 \%$ & This study \\
Hohenpeissenberg & NAIS & $5.5 \%$ & This study \\
Hyytiälä & Ion-DMPS & $6.4 \%$ & Gagné et al. (2007) \\
Hyytiälä & NAIS & $10 \%$ & Manninen et al. (2009a) \\
Jungfraujoch & NAIS & $27 \%$ & This study \\
Mace Head & NAIS & $1.7 \%$ & This study \\
Melpitz & NAIS & $1.0 \%$ & This study \\
Pallas & NAIS & $18 \%$ & This study \\
\hline
\end{tabular}

* Inclined Grid Mobility Analyzer, IGMA

(a)

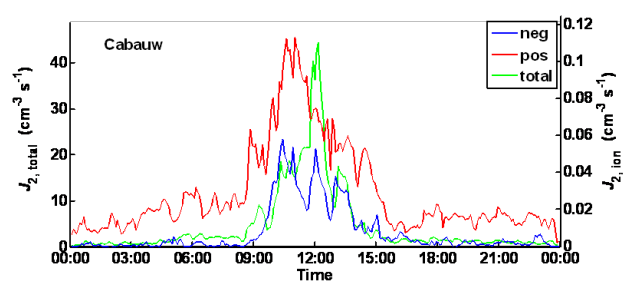

(c)

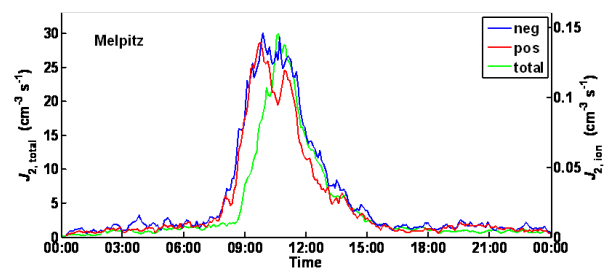

(b)

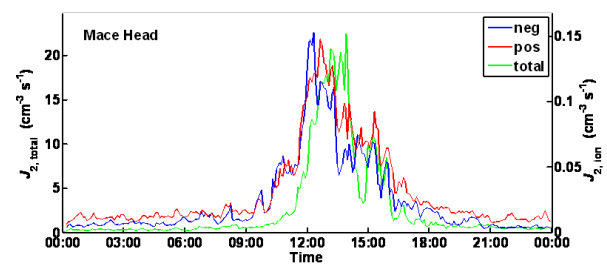

(d)

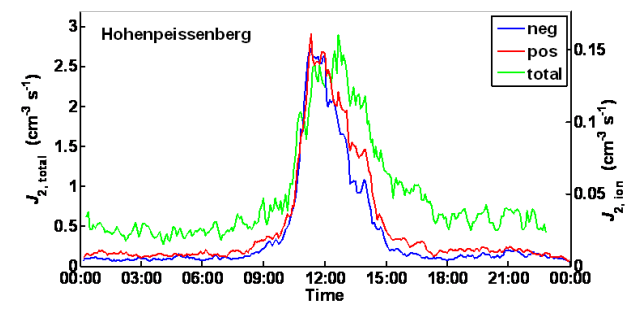

(e)

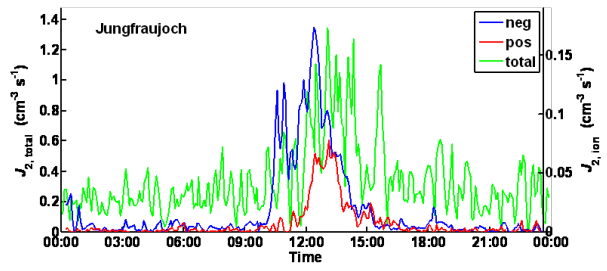

Fig. 9. Comparison of median charged and total particle formation rates during NPF events on 2008-2009 in (a) Cabauw, (b) Mace Head, (c) Melpitz, (d) Hohenpeissenberg, and (e) Jungfraujoch. Charged formation rates are measured with a (N)AIS in ion mode (negative ions, blue line and positive ions, red line). Uncharged formation rates are measured with a NAIS in particle mode (total particles, green line).

of atmospheric clusters and nano-particles by a network of ground-based measurements. Concretely, air ion spectrometer measurements were conducted rather continuously at 12 field sites across Europe from March 2008 to May 2009. This unique data set quantifies the spatial and temporal variation of the particle formation events and different NPF parameters, such as particle formation and growth rates (Manninen et al., 2009a).
As expected based on earlier overview studies (Kulmala et al., 2004c; Kulmala and Kerminen, 2008) and previous longterm data records at some of the measurement stations, we can conclude that new particle formation is a frequent phenomenon taking place in many kinds of environments. In this study particle formation bursts were observed almost exclusively during daytime, starting preferably before noon, which confirms the important role of photochemistry in this process (e.g. Kulmala et al., 2004c). In most cases, the growth of the newly formed particles could be followed over many hours, 
indicating that the aerosol formation took place over vast regional scales. No clear relation between the values of condensation sink and the strength and frequency of new particle formation events between the different sites were observed.

Different seasonal cycles were observed in nucleation event frequencies between different measurement sites. In the first group of the sites (Hyytiälä, Vavihill, Cabauw and Jungfraujoch), events showed a late spring-early summer maximum and a winter minimum. The second group of sites (Mace Head, Melpitz and K-Puszta) showed a similar seasonal cycle, but with an amplified frequency of the events. The third group of sites included only Finokalia, having a maximum new particle formation occurrence during the winter months. The last group of sites (Pallas, Hohenpeissenberg, Puy de Dôme and San Pietro Capofiume) displayed no clear seasonal cycle in the frequency of new particle formation events.

The growth rates of new particles were found to be of the order of a few nanometers per hour, varying within a factor of 3 between the different environments. At most sites, the particle growth rate increased with increasing particle size. The total formation rate at $2 \mathrm{~nm}$ varied by more than an order of magnitude between the different sites, whereas the formation rate of charged particles showed much less variation. This implies that the ion cluster concentration is much more stable regardless of the surroundings, whereas neutral clusters are dependent on the environment (in agreement with the suggestion of Gagné et al., 2010a). The systematic measurements performed within the EUCAARI project support the earlier observations on the contribution of ions to total particle formation in the boreal forest (Laakso et al., 2007b; Kulmala et al., 2007; Gagne et al., 2008; Manninen et al., 2009a) and in other environments (e.g. Iida et al., 2006; Eisele et al., 2006; Mirme et al., 2010; Boulon et al., 2010a, b). The results infer that ion-induced nucleation has a minor contribution to particle formation in the boundary layer in most environments.

The data set collected using cluster spectrometers during the continuous EUCAARI field measurements is huge, containing more than a thousand new particle formation event days. In the future, this data set will be used for evaluating large atmospheric modeling frameworks, as well as for deriving new nucleation parameterizations for such models. Our next focus is on quantifying the conditions that favor new particle formation in different environments. Trajectory analysis will be included in the analysis in order to estimate the regional aerosol source apportionment and the spatial scale of new particle formation events.

\section{Appendix A}

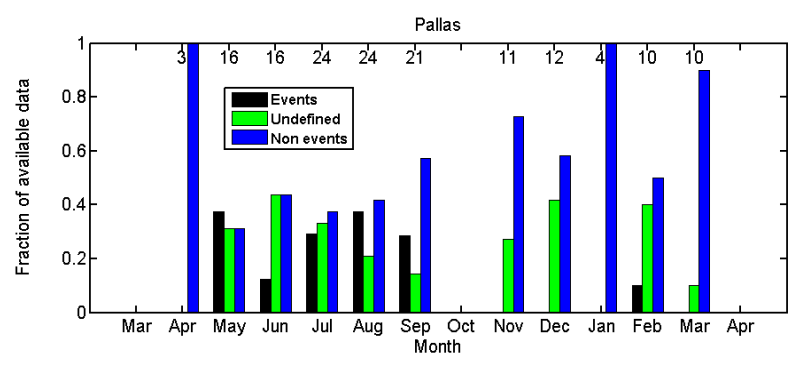

Fig. A1. The fraction of event, undefined and non-event days out of all analyzed days during each month in the year at Pallas, Finland, during April 2008-April 2009. The numbers above the figure refer to the number of days included in the analysis. (The same applies to the subsequent figures.)

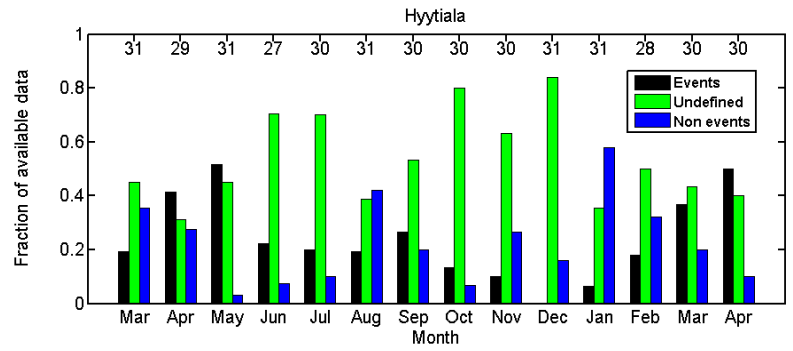

Fig. A2. The fraction of event, undefined and non-event days out of all analyzed days during each month in the year at Hyytiälä, Finland, during March 2008-April 2009.

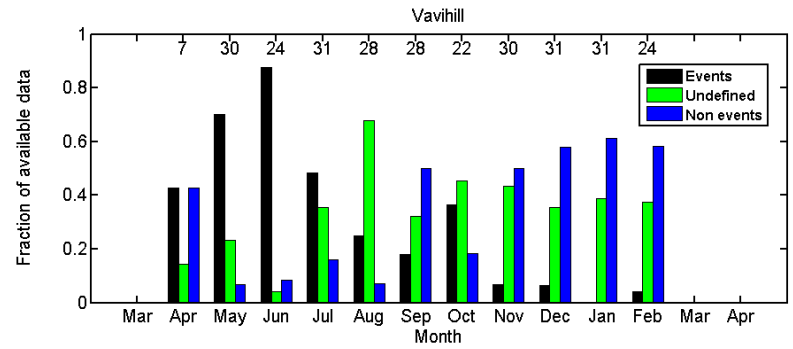

Fig. A3. The fraction of event, undefined and non-event days out of all analyzed days during each month in the year at Vavihill, Sweden, during April 2008-February 2009.

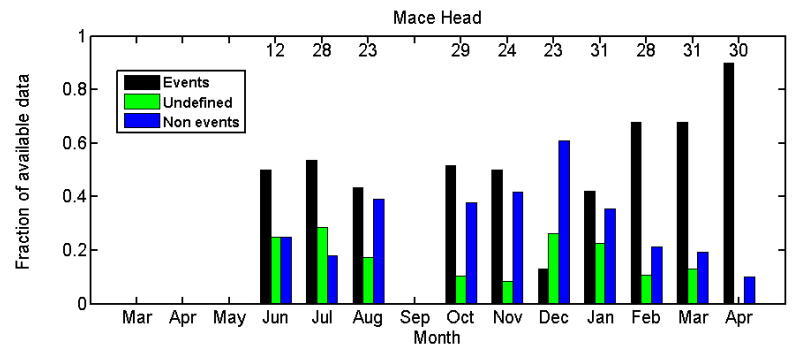

Fig. A4. The fraction of event, undefined and non-event days out of all analyzed days during each month in the year at Mace Head, Ireland, during June 2008-April 2009. 
Table A1. The classification of different particle formation event, undefined and non-event days based on the ion spectrometer data (according to methods introduced earlier by Dal Maso et al., 2005, and Hirsikko et al., 2007).

\begin{tabular}{ll}
\hline Class & Description \\
\hline Event Ia & $\begin{array}{l}\text { Growth of new particles was clearly seen in the size distribution data and it started at the sizes } \\
\text { close to cluster ion mode. We are able to use these events when analysing e.g. the growth rates of } \\
\text { particles or other parameters that characterize the event. }\end{array}$ \\
Ib & $\begin{array}{l}\text { The formation of new particles continued for several hours and the events had a clear shape. } \\
\text { II }\end{array}$ \\
their further study and the growth rate is obtainable only for some of these events. \\
Aump & $\begin{array}{l}\text { A distinct new mode of particles appears in the size range of nucleation mode and the nucleation } \\
\text { burst starts directly from the cluster ions region. However particles do not usually grow larger } \\
\text { than } 10 \text { nm in diameter. }\end{array}$ \\
Apple & $\begin{array}{l}\text { The characteristic feature is that the particle formation events of charged particles did not start } \\
\text { from the cluster ion mode and a clear gap in the ion distribution is observed between the cluster } \\
\text { and the nucleation modes. }\end{array}$ \\
Featureless & $\begin{array}{l}\text { We classified days as featureless nucleation days when formation of nucleation mode ions was } \\
\text { clearly observed but we were not able to classify such events to any specific event class. }\end{array}$ \\
\hline Undefined & $\begin{array}{l}\text { A new mode in the size range larger than } 25 \text { nm in diameter is observed and some growth is seen } \\
\text { in this mode. }\end{array}$ \\
\hline Non-event & $\begin{array}{l}\text { Extremely low concentration or noise of the instrument at the nucleation mode size range caused } \\
\text { problems to define whether an event occurred or not. }\end{array}$ \\
\hline
\end{tabular}

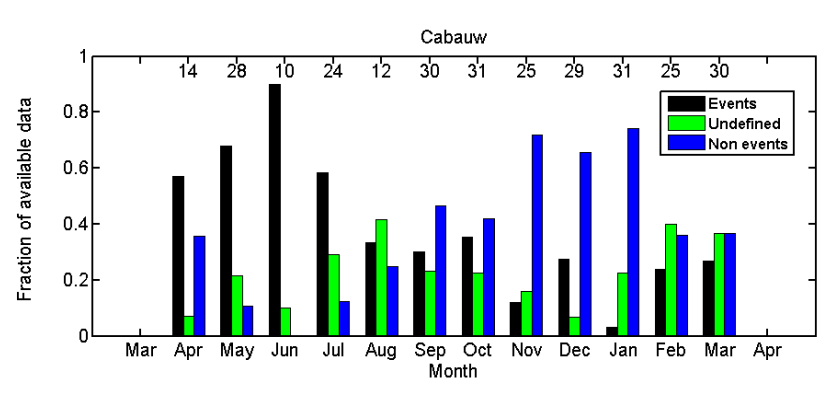

Fig. A5. The fraction of event, undefined and non-event days out of all analyzed days during each month in the year at Cabauw, Netherlands, during April 2008-March 2009.

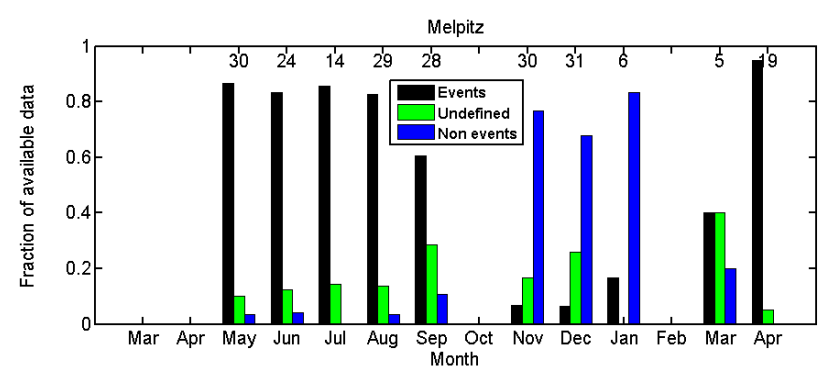

Fig. A6. The fraction of event, undefined and non-event days out of all analyzed days during each month in the year at Melpitz, Germary, during May 2008-April 2009.

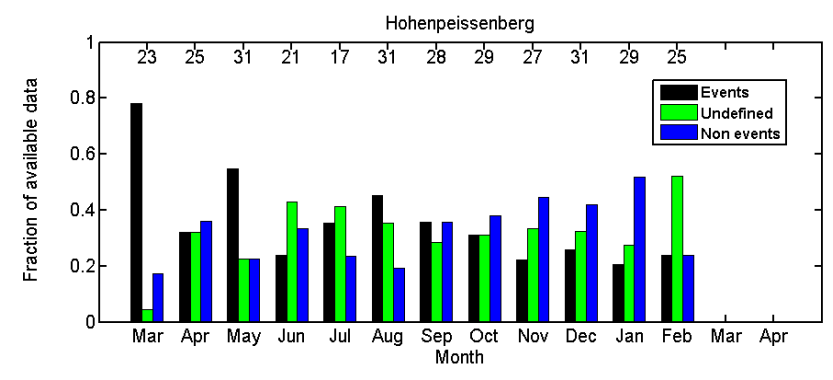

Fig. A7. The fraction of event, undefined and non-event days out of all analyzed days during each month in the year at Hohenpeissenberg, Germany, during April 2008-April 2009.

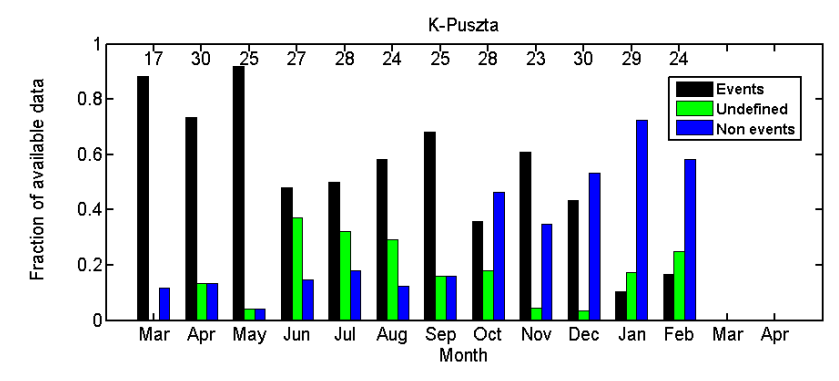

Fig. A8. The fraction of event, undefined and non-event days out of all analyzed days during each month in the year at K-puszta, Hungary, during March 2008-February 2009. 


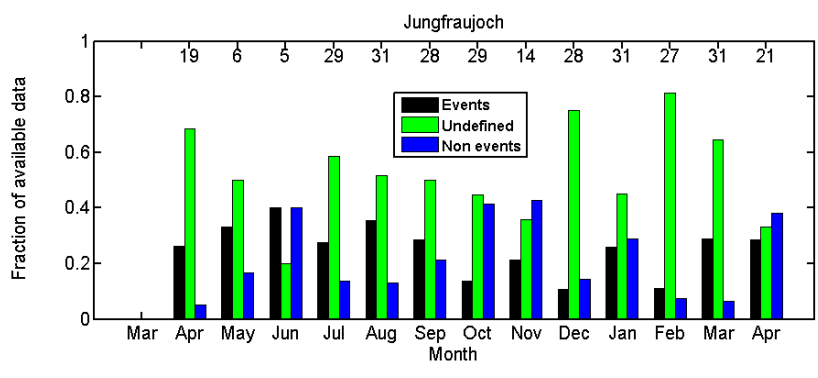

Fig. A9. The fraction of event, undefined and non-event days out of all analyzed days during each month in the year at Jungfraujoch, Switzerland, during April 2008-April 2009.

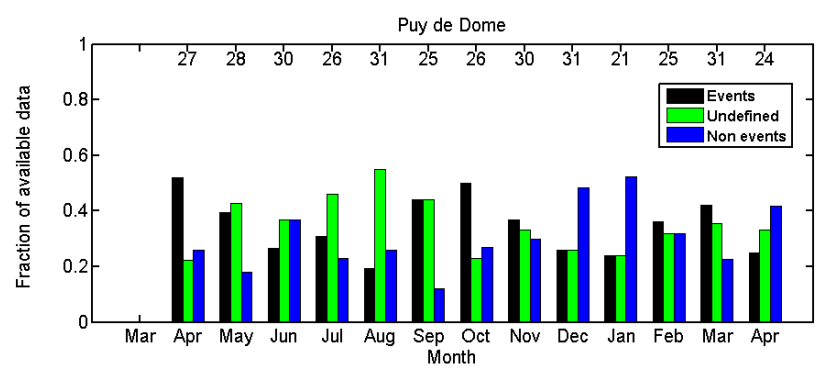

Fig. A10. The fraction of event, undefined and non-event days out of all analyzed days during each month in the year at Puy de Dôme, France, during April 2008-April 2009.

Acknowledgements. We thank all the researchers, technical staff and students who took part in the field measurements within the EUCAARI project. This work has been supported by European Commission 6th Framework program projects: EUCAARI, contract no. 036833-2 (EUCAARI) and EUSAAR, contract no. 026140 (EUSAAR). The support by the Academy of Finland Centre of Excellence program (project no. 211483, 211484 and 1118615) is also gratefully acknowledged. EPA Ireland is acknowledged for research support at Mace Head. Support from CNRS-INSU under LEFE-CHAT program for performing AIS measurements at Puy de Dôme is greatly acknowledged. We thank the International Foundation High Altitude Research Stations Jungfraujoch and Gornergrat (HFSJG) for the opportunity to perform experiments at the Jungfraujoch.

Edited by: U. Pöschl

\section{References}

Amato, P., Parazols, M., Sancelme, M., Mailhot, G., Laj, P., and Delort, A.-M.: An important oceanic source of micro-organisms for cloud water at the Puy de Dôme (France), Atmos. Environ., 41, 8253-8263, 2007.

Andreae, M. O. and Rosenfeld, D.: Aerosol-cloud-precipitation interactions. Part 1. The nature and sources of cloud-active particles, Earth-Sci. Rev., 89, 13-41, 2008.

Asmi, E., Sipilä, M., Manninen, H. E., Vanhanen, J., Lehtipalo, K., Gagné, S., Neitola, K., Mirme, A., Mirme, S., Tamm, E., Uin, J.,

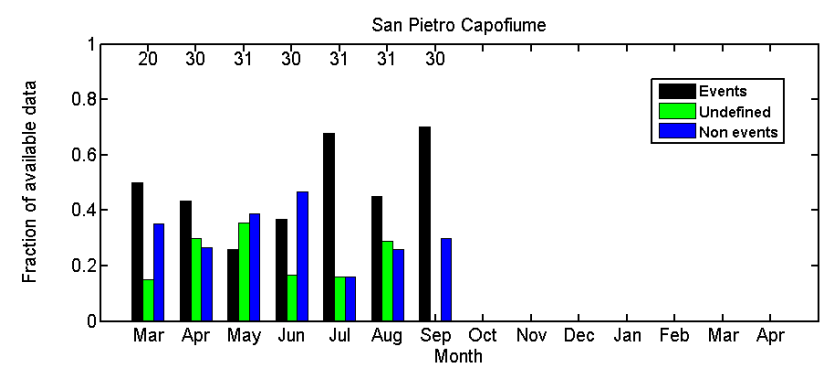

Fig. A11. The fraction of event, undefined and non-event days out of all analyzed days during each month in the year at San Pietro Capofiume, Italy, during March-September 2008.

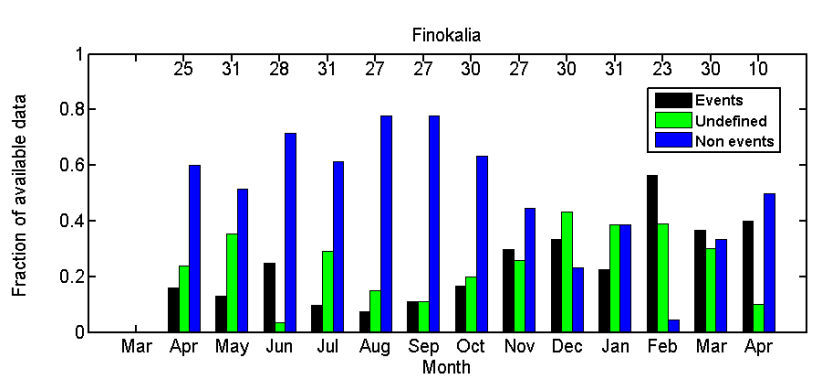

Fig. A12. The fraction of event, undefined and non-event days out of all analyzed days during each month in the year at Finokalia, Greece, during April 2008-April 2009.

Komsaare, K., Attoui, M., and Kulmala, M.: Results of the first air ion spectrometer calibration and intercomparison workshop, Atmos. Chem. Phys., 9, 141-154, doi:10.5194/acp-9-141-2009, 2009.

Baltensperger, U., Schwikowski, M., Jost, D. T., Nyeki, S., Gaeggeler, H. W., and Poulida, O.: Scavenging of atmospheric constituents in mixed phase clouds at the high-alpine site Jungfraujoch part I: Basic concept and aerosol scavenging by clouds, Atmos. Environ., 32, 3975-3983, 1998.

Birmili, W. and Wiedensohler, A.: New particle formation in the continental boundary layer: Meteorological and gas phase parameter influence, Geophys. Res. Lett., 27, 3325-3328, 2000.

Birmili, W., Wiedensohler, A., Heintzenberg, J., and Lehmann, K.: Atmospheric particle number size distribution in Central Europe: Statistical relations to air masses and meteorology, J. Geophys. Res., 106, 32005-32018, 2001.

Birmili, W., Berresheim, H., Plass-Dülmer, C., Elste, T., Gilge, S., Wiedensohler, A., and Uhrner, U.: The Hohenpeissenberg aerosol formation experiment (HAFEX): a longterm study including size-resolved aerosol, $\mathrm{H}_{2} \mathrm{SO}_{4}, \mathrm{OH}$, and monoterpenes measurements, Atmos. Chem. Phys., 3, 361-376, doi:10.5194/acp-3-361-2003, 2003.

Birmili, W., Weinhold, K., Nordmann, S., Wiedensohler, A., Spindler, G., Müller, K., Herrmann, H., Gnauk, T.. Pitz, M., Cyrys, J., Flentje, H., Nickel, C., Kuhlbusch, T. A. J., Löschau, G., Haase, D., Meinhardt, F., Schwerin, A., Ries, L., and Wirtz, K.: Atmospheric aerosol measurements in the German Ultrafine Aerosol Network (GUAN): Part 1 - soot and particle number size 
distributions, Gefahrst. Reinh. Luft, 69, 137-145, 2009.

Bonn, B., Boy, M., Kulmala, M., Groth, A., Trawny, K., Borchert, S., and Jacobi, S.: A new parametrization for ambient particle formation over coniferous forests and its potential implications for the future, Atmos. Chem. Phys., 9, 8079-8090, doi:10.5194/acp-9-8079-2009, 2009.

Boulon, J., Sellegri, K., Venzac, H., and Laj, P.: Long-term Observations of High Altitude Nucleation events, puy de Dôme, France, in preparation, 2010a.

Boulon, J., Sellegri, K., Venzac, H., Picard, D., Weingartner, E., Wehrle, G., Baltensperger, U., and Laj, P.: New particle formation and ultrafine charged aerosol climatology at a high altitude site in the Alps (Jungfraujoch, $3580 \mathrm{~m}$ a.s.l., Switzerland), Atmos. Chem. Phys. Discuss., 10, 11361-11399, doi:10.5194/acpd-10-11361-2010, 2010b.

Boy, M. and Kulmala, M.: Nucleation events in the continental boundary layer: Influence of physical and meteorological parameters, Atmos. Chem. Phys., 2, 1-16, doi:10.5194/acp-2-1-2002, 2002.

Dal Maso, M., Kulmala, M., Riipinen, I., Wagner, R., Hussein, T., Aalto, P. P., and Lehtinen, K. E. J.: Formation and growth of fresh atmospheric aerosols: eight years of aerosol size distribution data from SMEAR II, Hyytiälä, Finland, Boreal Env. Res., 10, $323-$ 336, 2005 .

Dal Maso, M., Sogacheva, L., Aalto, P., Riipinen, I., Komppula, M., Tunved, P., Korhonen, L., Suur-Uski, V., Hirsikko, A., Kurtén, T., Kerminen, V.-M., Lihavainen, H., Viisanen, Y., Hansson, H.C., and Kulmala, M.: Aerosol size distribution measurements at four Nordic field stations: identification, analysis and trajectory analysis of new particle formation bursts, Tellus, 59B, 350-361, 2007.

Ehn, M., Vuollekoski, H., Petäjä, T., Kerminen, V.-M. , Vana, M., Aalto, P., de Leeuw, G., Ceburnis, D., Dupuy, R., O’Dowd, C., and Kulmala, M.: Growth Rates During Coastal and Marine New Particle Formation in Western Ireland, J. Geophys. Res., doi:10.1029/2010JD014292, in press, 2010.

Eisele, F. L., Lovejoy, E. R., Kosciuch, E., Moore, K. F., Mauldin III, R. L., Smith, J. N., McMurry, P. H., and Iida, K.: Negative atmospheric ions and their potential role in ion-induced nucleation, J. Geophys. Res., 111, D04305, doi:10.1029/2005JD006568, 2006.

Enghoff, M. B. and Svensmark, H.: The role of atmospheric ions in aerosol nucleation - a review, Atmos. Chem. Phys., 8, 49114923, doi:10.5194/acp-8-4911-2008, 2008.

Engler, C., Rose, D., Wehner, B., Wiedensohler, A., Brggemann, E., Gnauk, T., Spindler, G., Tuch, T., and Birmili, W.: Size distributions of non-volatile particle residuals $(D p<800 \mathrm{~nm})$ at a rural site in Germany and relation to air mass origin, Atmos. Chem. Phys., 7, 5785-5802, doi:10.5194/acp-7-5785-2007, 2007.

Gagné, S., Laakso, L., Petäjä, T., Kerminen, V.-M., and Kulmala, M.: Analysis of one year of Ion-DMPS data from the SMEAR II station, Finland, Tellus, 60B, 318-329, 2008.

Gagné, S., Nieminen, T., Kurtén, T., Manninen, H. E., Petäjä, T., Laakso, L., Kerminen, V.-M., Boy, M., and Kulmala, M.: Factors influencing the contribution of ion-induced nucleation in a boreal forest, Finland, Atmos. Chem. Phys., 10, 3743-3757, doi:10.5194/acp-10-3743-2010, 2010a.

Gagné, S., Lehtipalo, K., Manninen, H. E., Franchin, A., Nieminen, T., Schobesberger, S., Yli-Juuti, T., Boulon, J., Hõrrak, U.,
Mirme, A., Mirme, S., Sonntag, A., Asmi, E., Kulmala, M. and Petäjä, T.: Intercomparison of air ion spectrometers: a basis for interpretation, in preparation, 2010b.

Hakola, H, Tarvainen, V., Laurila, T., Hiltunen, V., Hellen, H., and Keronen, P.: Seasonal variation of VOC concentrations above a boreal coniferous forest, Atmos. Environ., 37, 1623-1634, 2003.

Hamed, A., Joutsensaari, J., Mikkonen, S., Sogacheva, L., Dal Maso, M., Kulmala, M., Cavalli, F., Fuzzi, S., Facchini, M. C., Decesari, S., Mircea, M., Lehtinen, K. E. J., and Laaksonen, A.: Nucleation and growth of new particles in Po Valley, Italy, Atmos. Chem. Phys., 7, 355-376, doi:10.5194/acp-7-355-2007, 2007.

Hamed, A., Birmili, W., Joutsensaari, J., Mikkonen, S., Asmi, A., Wehner, B., Spindler, G., Jaatinen, A., Wiedensohler, A., Korhonen, H., Lehtinen, K. E. J., and Laaksonen, A.: Changes in the production rate of secondary aerosol particles in Central Europe in view of decreasing $\mathrm{SO}_{2}$ emissions between 1996 and 2006, Atmos. Chem. Phys., 10, 1071-1091, doi:10.5194/acp-10-10712010, 2010.

Hari, P. and Kulmala, M.: Station for measuring ecosystematmosphere relations (SMEAR II), Boreal Env. Res., 10, 315322, 2005.

Hatakka, J., Aalto, T., Aaltonen, V., Aurela, M., Hakola, H., Komppula, M., Laurila, T., Lihavainen, H., Paatero, J., Salminen, K., and Viisanen, Y.: Overview of the atmospheric research activities and results at Pallas GAW station, Boreal Env. Res., 8, 365-383, 2003.

Hirsikko, A., Laakso, L., Hörrak, U., Aalto, P. P., Kerminen, V.M., and Kulmala, M.: Annual and size dependent variation of growth rates and ion concentrations in boreal forest, Boreal Env. Res., 10, 357-369, 2005.

Hirsikko, A., Bergman, T., Laakso, L., Dal Maso, M., Riipinen, I., Hrrak, U., and Kulmala, M.: Identification and classification of the formation of intermediate ions measured in boreal forest, Atmos. Chem. Phys., 7, 201-210, doi:10.5194/acp-7-201-2007, 2007.

Hoffmann, T., O’Dowd, C. D., and Seinfeld, J. H.: Iodine oxide homogeneous nucleation: An explanation for coastal new particle production, Geophys. Res. Lett., 28, 1949-1952, 2001.

Horváth, L. and Sutton, M. A.: Long-term record of ammonia and ammonium concentrations at K-puszta, Hungary, Atmos. Environ., 32, 339-344, 1998.

Hõrrak, U., Salm, J., and Tammet, H.: Bursts of intermediate ions in atmospheric air, J. Geophys. Res.-Atmos., 103(D12), 13909 13915, 1998.

Hõrrak, U.: Air Ion Mobility Spectra at a rural area, PhD Thesis, University of Tartu, Estonia, 2001.

Hõrrak, U., Salm, J., and Tammet, H.: Diurnal variation in the concentration of air ions of different mobility classes in a rural area. J. Geophys. Res., 108, 4653, doi:10.1029/2002JD003240, 2003.

Iida, K., Stolzenburg, M., McMurry, P. H., Dunn, M. J., Smith, J. N., Eisele, F., and Keady, P.: Contribution of ion-induced nucleation to new particle formation: Methodology and its application to atmospheric observations in Boulder, Colorado, J. Geophys. Res., 111, D23201, doi:10.1029/2006JD007167, 2006.

Iida, K., Stolzenburg, M. R., McMurry, P. H., and Smith, J. N.: Estimating nanoparticle growth rates from sizedependent charged fractions: Analysis of new particle formation events in Mexico City, J. Geophys. Res., 113, D05207, 
doi:10.1029/2007JD009260, 2008.

Jennings, S. G., Kleefeld, C., O’Dowd, C., Junker, C., Spain, T. G., O'Brien, P., Roddy, A. F., and O'Connor, T. C.: Mace Head atmospheric research station - Characterization of aerosol radiative parameters, Boreal Env. Res., 8, 303-314, 2003.

Kazil, J., Harrison, R. G., and Lovejoy, E. R.: Tropospheric new particle formation and the role of ions, Space Sci. Rev., 137, 241255, 2008

Kerminen, V.-M., Lehtinen, K. E. J., Anttila, T., and Kulmala, M.: Dynamics of atmospheric nucleation mode particles: A time scale analysis, Tellus, 56B, 135-146, 2004.

Kerminen, V.-M., Lihavainen, H., Komppula, M., Viisanen, Y., and Kulmala, M.: Direct observational evidence linking atmospheric aerosol formation and cloud droplet activation, Geophys. Res. Lett., 32, L14803, doi:10.1029/2005GL023130, 2005.

Kerminen, V.-M., Petäjä, T., Manninen, H. E., Paasonen, P., Nieminen, T., Sipilä, M., Junninen, H., Ehn, M., Gagné, S., Laakso, L., Riipinen, I., Vehkamäki, H., Kurten, T., Ortega, I. K., Dal Maso, M., Brus, D., Hyvärinen, A., Lihavainen, H., Leppä, J., Lehtinen, K. E. J., Mirme, A., Mirme, S., Hõrrak, U., Berndt, T., Stratmann, F., Birmili, W., Wiedensohler, A., Metzger, A., Dommen, J., Baltensperger, U., Kiendler-Scharr, A., Mentel, T. F., Wildt, J., Winkler, P. M., Wagner, P. E., Petzold, A., Minikin, A., PlassDülmer, C., Pöschl, U., Laaksonen, A., and Kulmala, M.: Atmospheric nucleation: highlights of the EUCAARI project and future directions, Atmos. Chem. Phys. Discuss., 10, 16497-16549, doi:10.5194/acpd-10-16497-2010, 2010.

Komppula, M., Lihavainen, H., Hatakka, J., Paatero, J., Aalto, P., Kulmala, M., and Viisanen, Y.: Observations of new particle formation and size distributions at two different heights and surroundings in subarctic area in northern Finland, J. Geophys. Res., 108(D9), 4295, doi:10.1029/2002JD002939, 2003.

Komppula, M., Sihto, S.-L., Korhonen, H., Lihavainen, H., Kerminen, V.-M., Kulmala, M., and Viisanen, Y.: New particle formation in air mass transported between two measurement sites in Northern Finland, Atmos. Chem. Phys., 6, 2811-2824, doi:10.5194/acp-6-2811-2006, 2006.

Kouvarakis, G., Tsigaridis, K., Kanakidou, M., and Mihalopoulos, N.: Temporal variations of surface regional background ozone over Crete Island in the Southeast Mediterranean, J. Geophys. Res., 105, 399-407, 2000.

Kristensson, A., Dal Maso, M., Swietlicki, E., Hussein, T., Zhou, J., Kerminen, V.-M., and Kulmala, M.: Characterization of new particle formation events at a background site in Southern Sweden: Relation to air mass history, Tellus, 60B, 330-344, 2008.

Kuang, C., Riipinen, I., Sihto, S.-L., Kulmala, M., McCormick, A. V., and McMurry, P. H.: An improved criterion for new particle formation in diverse atmospheric environments, Atmos. Chem. Phys. Discuss., 10, 491-521, doi:10.5194/acpd-10-4912010, 2010.

Kulmala, M., Dal Maso, M., Mäkelä, J. M., Pirjola, L., Väkevä, M., Aalto, P. P., Miikkulainen, P., Hämeri, K., and O’Dowd, C. D.: On the formation, growth and composition of nucleation mode particles, Tellus, 53B, 479-490, 2001a.

Kulmala, M., Hämeri, K., Aalto, P. P., Mäkelä, J. M., Pirjola, L., Nilsson, E. D., Buzorius, G., Rannik, Ü., Dal Maso, M., Seidl, W., Hoffman, T., Janson, R., Hansson, H.-C., Viisanen, Y., Laaksonen, A., and O'Dowd, C. D.: Overview of the international project on biogenic aerosol formation in the boreal forest (BIO-
FOR), Tellus, 53B, 324-343, 2001b.

Kulmala, M.: How particles nucleate and grow, Science, 302, 1000 1001, 2003.

Kulmala, M., Kerminen, V.-M., Anttila, T., Laaksonen, A., and O'Dowd, C. D.: Organic aerosol formation via sulphate cluster activation, J. Geophys. Res. 109(D4), 4205, doi:10.1029/2003JD003961, 2004a.

Kulmala, M., Laakso, L., Lehtinen, K. E. J., Riipinen, I., Dal Maso, M., Anttila, T., Kerminen, V.-M., Hõrrak, U., Vana, M., and Tammet, H.: Initial steps of aerosol growth, Atmos. Chem. Phys., 4, 2553-2560, doi:10.5194/acp-4-2553-2004, 2004b.

Kulmala, M., Vehkamäki, H., Petäjä, T., Dal Maso, M., Lauri, A., Kerminen, V.-M., Birmili, W., and McMurry, P. H.: Formation and growth rates of ultrafine atmospheric particles: A review of observations, J. Aerosol Sci., 35, 143-176, 2004c.

Kulmala, M., Riipinen, I., Sipilä, M., Manninen, H. E., Petäjä, T., Junninen, H., Dal Maso, M., Mordas, G., Mirme, A., Vana, M., Hirsikko, A., Laakso, L., Harrison, R. M., Hanson, I., Leung, C., Lehtinen, K. E. J., and Kerminen, V.-M.: Towards direct measurements of atmospheric nucleation, Science, 318, 89-92, 2007.

Kulmala, M. and Kerminen, V.-M.: On the growth of atmospheric nanoparticles, Atmos. Res., 90, 132-150, 2008.

Kulmala, M., Asmi, A., Lappalainen, H. K., Carslaw, K. S., Pöschl, U., Baltensperger, U., Hov, Ø., Brenquier, J.-L., Pandis, S. N., Facchini, M. C., Hansson, H.-C., Wiedensohler, A., and O'Dowd, C. D.: Introduction: European Integrated Project on Aerosol Cloud Climate and Air Quality interactions (EUCAARI) - integrating aerosol research from nano to global scales, Atmos. Chem. Phys., 9, 2825-2841, doi:10.5194/acp-9-2825-2009, 2009.

Kulmala, M., Riipinen, I., Nieminen, T., Hulkkonen, M., Sogacheva, L., Manninen, H. E., Paasonen, P., Petäjä, T., Dal Maso, M., Aalto, P. P., Viljanen, A., Usoskin, I., Vainio, R., Mirme, S., Mirme, A., Minikin, A., Petzold, A., Hõrrak, U., Plaß-Dülmer, C., Birmili, W., and Kerminen, V.-M.: Atmospheric data over a solar cycle: no connection between galactic cosmic rays and new particle formation, Atmos. Chem. Phys., 10, 1885-1898, doi:10.5194/acp-10-1885-2010, 2010.

Laakso, L., Grönholm, T., Kulmala, L., Haapanala, S., Hirsikko, A., Lovejoy, E. R., Kazil, J., Kurtén, T., Boy, M., Nilsson, E. D., Sogachev, A., Riipinen, I., Stratmann, F. and Kulmala, M.: Hotair balloon as a platform for boundary layer profile measurements during particle formation, Boreal Env. Res., 12, 279-294, 2007a.

Laakso, L., Gagné, S., Petäjä, T., Hirsikko, A., Aalto, P. P., Kulmala, M., and Kerminen, V.-M.: Detecting charging state of ultra-fine particles: instrumental development and ambient measurements, Atmos. Chem. Phys., 7, 1333-1345, doi:10.5194/acp-7-13332007, 2007b.

Laakso, L., Laakso, H., Aalto, P. P., Keronen, P., Petäjä, T., Nieminen, T., Pohja, T., Siivola, E., Kulmala, M., Kgabi, N., Molefe, M., Mabaso, D., Phalatse, D., Pienaar, K., and Kerminen, V.-M.: Basic characteristics of atmospheric particles, trace gases and meteorology in a relatively clean Southern African Savannah environment, Atmos. Chem. Phys., 8, 4823-4839, doi:10.5194/acp-8-4823-2008, 2008.

Laaksonen, A., Hamed, A., Joutsensaari, J., Hiltunen, L., Cavalli, F., Junkermann, W., Asmi, A., Fuzzi, S., and Facchini, M. C.: Cloud condensation nucleus production from nucleation events at a highly polluted region, Geophys. Res. Lett., 32, L06812, 
doi:10.1029/2004GL022092, 2005.

Maenhaut, W., Raes, N., Chi, X., Cafmeyer, J., and Wang, W.: Chemical composition and mass closure for $\mathrm{PM}_{2.5}$ and $\mathrm{PM}_{10}$ aerosols at K-puszta, Hungary, in summer 2006, X-ray Spectrometry, 37, 193-197, 2008.

Manninen, H. E., Nieminen, T., Riipinen, I., Yli-Juuti, T., Gagné, S., Asmi, E., Aalto, P. P., Petäjä, T., Kerminen, V.-M., and Kulmala, M.: Charged and total particle formation and growth rates during EUCAARI 2007 campaign in Hyytil, Atmos. Chem. Phys., 9, 4077-4089, doi:10.5194/acp-9-4077-2009, 2009a.

Manninen, H. E., Petäjä, T., Asmi, E., Riipinen, I., Nieminen, T., Mikkilä, J., Hõrrak, U., Mirme, A., Mirme, S., Laakso, L., Kerminen, V.-M., and Kulmala, M.: Long-term field measurements of charged and neutral clusters using Neutral cluster and Air Ion Spectrometer (NAIS), Boreal Env. Res., 14, 591-605, $2009 \mathrm{~b}$.

Marinoni, A., Laj, P., Sellegri, K., and Mailhot, G.: Cloud chemistry at the Puy de Dôme: variability and relationships with environmental factors, Atmos. Chem. Phys., 4, 715-728, doi:10.5194/acp-4-715-2004, 2004.

Merikanto, J., Spracklen, D. V., Mann, G. W., Pickering, S. J., and Carslaw, K. S.: Impact of nucleation on global CCN, Atmos. Chem. Phys., 9, 8601-8616, doi:10.5194/acp-9-8601-2009, 2009.

Mihalopoulos, N., Stephanou, E., Kanakidou, M., Pilitsidis, S., and Bousquet, P.: Tropospheric aerosol ionic composition above the eastern Mediterranean Area, Tellus, 49B, 314-326, 1997.

Mirme, A., Tamm, E., Mordas, G., Vana, M., Uin, J., Mirme, S., Bernotas, T., Laakso, L., Hirsikko, A., and Kulmala, M. A.: Wide-range multi-channel Air Ion Spectrometer, Boreal Env. Res., 12, 247-264, 2007.

Mirme, S., Mirme, A., Minikin, A., Petzold, A., Hõrrak, U., Kerminen, V. -M., and Kulmala, M.: Atmospheric sub-3 nm particles at high altitudes, Atmos. Chem. Phys., 10, 437-451, doi:10.5194/acp-10-437-2010, 2010.

Mäkelä, J. M., Riihelä, M., Ukkonen, A., Jokinen, V., and Keskinen, J.: Comparison of mobility equivalent diameter with KelvinThomson diameter using ion mobility data, J. Chem. Phys., 105, 1562-1571, 1996.

Nadykto, A. B. and Yu, F.: Uptake of neutral polar vapor molecules by charged clusters/particles: Enhancement due to dipole-charge interaction, J. Geophys. Res., 108, 4717, doi:10.1029/2003JD003664, 2003.

Nieminen, T., Manninen, H. E., Sihto, S.-L., Yli-Juuti, T., Mauldin III, R. L., Petäjä, T., Riipinen, I., Kerminen, V.-M., and Kulmala, M.: Connection of Sulfuric Acid to Atmospheric Nucleation in Boreal Forest, Environ. Sci. Technol., 43, 4715-4721, 2009.

Nilsson, E. D., Rannik, Ü, Buzorius, G, O’Dowd, C., Boy, M., Paatero, J., and Laakso, L.: Effects of the continental boundary layer evolution, convection, turbulence and entrainment on aerosol formation, Tellus, 53B, 441-461, 2001.

O’Connor, T. C., Jennings, S. G., and O’Dowd, C. D.: Highlights from 50 years of Aerosol Measurements at Mace Head, Atmos. Res., 90, 338-355, 2008.

O’Dowd, C. D., Hämeri, K., Mäkelä, J., Väkevä, M., Aalto, P., de Leeuw, G., Kuntz, G. J., Becker, E., Hansson, H.-C., Allen , A. G., Harrison, R. M., Berresheim, H., Kleefeld, C., Geever, M., Jennings, S. G., and Kulmala, M.: Coastal new particle formation: Environmental conditions and aerosol physicochemical characteristics during nucleation bursts, J. Geophys. Res., 107,
8107, doi:10.1029/2000JD000206, 2002.

O’Dowd, C. D. and Hoffmann, T.: Coastal New Particle Formation: A Review of the Current State-Of-The-Art, Environ. Chem., 2, 245-255, 2005.

Paasonen, P., Sihto, S.-L., Nieminen, T., Vuollekoski, H., Riipinen, I., Plaß-Dülmer, C., Berresheim, H., Birmili, W., and Kulmala, M.: Connection between new particle formation and sulphuric acid at Hohenpeissenberg (Germany) including the influence of organic compounds, Boreal Env. Res., 14, 616-629, 2009.

Pierce, J. R. and Adams, P. J.: Uncertainty in global CCN concentrations from uncertain aerosol nucleation and primary emission rates, Atmos. Chem. Phys., 9, 1339-1356, doi:10.5194/acp-91339-2009, 2009.

Pikridas, M., Bougiatioti, A., Hildebrandt, L., Engelhart, G. J., Kostenidou, E., Mohr, C., Prévôt, A. S. H., Kouvarakis, G., Zarmpas, P., Burkhart, J. F., Lee, B.-H., Psichoudaki, M., Mihalopoulos, N., Pilinis, C., Stohl, A., Baltensperger, U., Kulmala, M., and Pandis, S. N.: The Finokalia Aerosol Measurement Experiment - 2008 (FAME-08): an overview, Atmos. Chem. Phys., 10, 6793-6806, doi:10.5194/acp-10-6793-2010, 2010.

Putaud, J.-P., Raes, F., Van Dingenen, R., Brüggemann, E., Facchini, M.-C., Decesari, S., Fuzzi, S., Gehrig, R., Hüglin, C., Laj, P., Lorbeer, G., Maenhaut, W., Mihalopoulos, N., Müller, K., Querol, X., Rodriguez, S., Schneider, J., Spindler, G., ten Brink, H., Torseth, K., and Wiedensohler, A.: A European aerosol phenomenology - 2: chemical characteristics of particulate matter at, kerbsite, urban, rural and background sites in Europe, Atmos. Environ., 38, 2579-2595, 2004.

Sellegri, K., Laj, P., Dupuy, R., Legrand, M., Preunkert, S., and Putaud, J.-P.: Size-dependent scavenging efficiencies of multicomponent atmospheric aerosols in clouds, J. Geophys. Res., 108, 4334, doi:10.1029/2002JD002749, 2003.

Sellegri, K., Yoon, Y. J., Jennings, S. G., O’Dowd, C. D., Pirjola, L., Cautenet, S., Hongwei Chen, and Hoffmann, T.: Quantification of Coastal New Ultra-Fine Particles Formation from In situ and Chamber Measurements during the BIOFLUX Campaign, Environ. Chem., 2, 260-270, 2005.

Sipilä, M., Berndt, T., Petäjä, T. Brus, T., Vanhanen, J., Stratmann, F., Patokoski, J., Mauldin III, R. L., Hyvärinen, A.-P., Lihavainen, H., and Kulmala, M.: The Role of Sulphuric Acid in Atmospheric Nucleation, Science, 327, 1243-1246, 2010.

Sogacheva, L., Saukkonen, L., Nilsson, E. D., Dal Maso, M., Schultz, D., de Leeuw, G., and Kulmala, M.: New aerosol particle formation in different synoptic situations at Hyytiälä, southern Finland, Tellus, 60B, 485-494, 2008.

Spindler, G., Müller, K., Brüggemann, E., Gnauk, T., and Herrmann, H.: Long-term size-segregated characterization of $\mathrm{PM}_{10}$, $\mathrm{PM}_{2.5}$, and $\mathrm{PM}_{1}$ at the IfT research station Melpitz downwind of Leipzig (Germany) using high and low-volume filter samplers, Atmos. Environ., 38, 5333-5347, 2004.

Spracklen, D. V., Carslaw, K. S., Kulmala, M., Kerminen, V.-M., Sihto, S.-L., Riipinen, I., Merikanto, J., Mann, G. W., Chipperfield, M. P., Wiedensohler, A., Birmili, W., and Lihavainen, H.: Contribution of particle formation to global cloud condensation nuclei concentrations, Geophys. Res. Lett., 35, L06808, doi:10.1029/2007GL033038, 2008.

Suni, T., Kulmala, M., Hirsikko, A., Bergman, T., Laakso, L., Aalto, P. P., Leuning, R., Cleugh, H., Zegelin, S., Hughes, D., van Gorsel, E., Kitchen, M., Vana, M., Hõrrak, U., Mirme, S., 
Mirme, A., Sevanto, S., Twining, J., and Tadros, C.: Formation and characteristics of ions and charged aerosol particles in a native Australian Eucalypt forest, Atmos. Chem. Phys., 8, 129-139, doi:10.5194/acp-8-129-2008, 2008.

Tammet, H. and Kulmala, M.: Simulation tool for atmospheric aerosol nucleation bursts, J. Aerosol Sci., 36, 173-196, 2005.

Tammet, H.: Continuous scanning of the mobility and size distribution of charged clusters and nanometer particles in atmospheric air and the Balanced Scanning Mobility Analyzer BSMA, Atmos. Res., 82, 523-535, 2006.

Tunved, P. Hansson, H.-C., Kerminen, V.-M., Ström, J., Dal Maso, M., Lihavainen, H., Viisanen, Y., Aalto, P. P., Komppula, M., and Kulmala, M.: High natural aerosol loading over Boreal forests, Science, 312, 261-263, 2006.

Van Ulden, A. and Wieringa, J.: Atmospheric boundary layer research at Cabauw, Bound.-Lay. Meteorol., 78, 39-69, 1996.

Vana, M., Ehn, M., Petäjä, T., Vuollekoski, H., Aalto, P., de Leeuw, G., Ceburnis, D., O'Dowd, C.D., and Kulmala, M.: Characteristic features of air ions at Mace Head on the west coast of Ireland, Atmos. Res., 90, 278-286, 2008.

Vartiainen, E., Kulmala, M., Ehn, M., Hirsikko, A., Junninen, H., Petäjä, T., Sogacheva, L., Kuokka, S., Hillamo, R., Skorokhod, A., Belikov, I., Elansky, N. and Kerminen, V.-M.: Ion and particle number concentrations and size distributions along the TransSiberian railroad, Boreal Env. Res., 12, 375-396, 2007.

Venzac, H., Sellegri, K., and Laj, P.: Nucleation events detected at the high altitude site of the Puy de Dôme Research Station, France, Boreal Env. Res., 12, 345-359, 2007.

Venzac, H., Sellegri, K., Laj, P., Villani, P., Bonasoni, P., Marinoni, A., Cristofanelli, P., Calzolari, F., Fuzzi, S., Decesari, S., Facchini, M. C., Vuillermoz, E., and Verza, G. P.: High Frequency New Particle Formation in the Himalayas, P. Natl. Acad. Sci., 105, 15666-15671, 2008.

Virkkula, A., Hirsikko, A., Vana, M., Aalto, P. P., Hillamo, R., and Kulmala, M.: Charged particle size distributions and analysis of particle formation events at the Finnish Antarctic research station Aboa, Boreal Env. Res., 12, 397-408, 2007.

Weber, R. J., Marti, J. J., McMurry, P. H., Eisele, F. L., Tanner, D. J., and Jefferson, A.: Measured atmospheric new particle formation rates: Implications for nucleation mechanisms, Chem. Eng. Comm., 151, 53-64, 1996.
Weingartner, E., Nyeki, S., and Baltensperger, U.: Seasonal and diurnal variation of aerosol size distributions $(10<\mathrm{D}<750 \mathrm{~nm})$ at a high-alpine site (Jungfraujoch $3580 \mathrm{~m}$ asl), J. Geophys. Res., 104, 26809-26820, 1999.

Wiedensohler, A, Chen, Y. F., Nowak, A, Wehner, B., Achtert, P, Berghof, M., Birmili, W., Wu, Z. J., Hu, M., Zhu, T., Takegawa, N., Kita, K., Kondo, Y., Lou, S. R., Hofzumahaus, A, Holland, F, Wahner, A., Gunthe, S. S., Rose, D., Su, H., and Pöschl, U.: Rapid aerosol particle growth and increase of cloud condensation nucleaus activity by secondary aerosol formation and condensation: A case study for regional air pollution in northeastern China, J. Geophys. Res., 114, D00G08, doi:10.1029/2008JD010884, 2009.

Winkler, P. M., Steiner, G., Vrtala, A., Vehkamäki, H., Noppel, M., Lehtinen, K. E. J., Reischl, G. P., Wagner, P. E., and Kulmala, M.: Heterogeneous nucleation experiments bridging the scale from molecular ion clusters to nanoparticles, Science, 319 , 1374-1377, doi:10.1126/science.1149034, 2008.

Wobrock, W., Flossmann, A. I., Monier, M., Pichon, J.-M., Cortez, L., Fournol, J.-F., Schwarzenböck, A., Mertes, S., Heintzenberg, J., Laj, P., Orsi, G., Ricci, L., Fuzzi, S., Brink, H. T., Jongejan, P., and Otjes, R.: The Cloud Ice Mountain Experiment (CIME) 1998: experiment overview and modelling of the microphysical processes during the seeding by isentropic gas expansion, Atmos. Res., 58, 231-265, 2001.

Yli-Juuti, T., Riipinen, I., Aalto, P. P., Nieminen, T., Maenhaut, W., Janssens, I. A., Claeys, M., Salma, I., Ocskay, R., Hoffer, A., Imre, K., and Kulmala, M.: Characteristics of new particle formation events and cluster ions at K-puszta, Hungary, Boreal Env. Res., 14, 683-698, 2009.

Yoon, Y. J., O'Dowd C. D., Jennings, S. G., and Lee, S. H.: Statistical characteristics and predictability of particle formation events at Mace Head, J. Geophys. Res., 111, D13204, doi:10.1029/2005JD006284, 2006.

Yu, F., Wang, Z., Luo, G., and Turco, R.: Ion-mediated nucleation as an important global source of tropospheric aerosols, Atmos. Chem. Phys., 8, 2537-2554, doi:10.5194/acp-8-2537-2008, 2008. 